\title{
Editorial Perspective
}

\section{A Great Little Man: The Shadow of Jair Bolsonaro}

\author{
Jeffery R. Webber \\ Department of Politics, York University, Toronto \\ jrwebber@yorku.ca
}

\begin{abstract}
This editorial perspective attempts to explain the recent rise of Jair Bolsonaro to the presidency in Brazil and to characterise, at least in a preliminary fashion, the nature of the new regime one year into Bolsonaro's rule. The core argument is that Bolsonaro represents a weak and internally-fragmented far-right regime, with unenthusiastic and declining popular support. Dominant sections of international and domestic capital operating in Brazil lent Bolsonaro electoral backing as a last way out of economic and political crisis, but so far, the new government has failed in sufficiently guaranteeing their most important interests and the markets are withdrawing approval. Themes covered include the political paralysis of the new regime, the social bases of Bolsonarismo, the nature of the current state-capital relation, and the role of evangelical Pentecostalism in far-right Brazilian politics today. A biographical portrait of Bolsonaro is provided, alongside a mapping of the dominant factions of the new administration. Finally, an assessment of the economic outlook in Brazil is developed, together with speculation as to the likely political consequences in the short- to medium-term future.
\end{abstract}

\section{Keywords}

Brazil - Bolsonaro - far-right - authoritarianism - political economy - evangelical 
Running on the ticket of the little-known Social Liberal Party (PSL) in Brazil's general election in October 2018, the virtually unknown Jair Bolsonaro, a former army captain and marginal congressperson representing a Rio de Janeiro riding since the early 199os, promised to be tough on crime and corruption. ${ }^{1}$ Cultivating an outsider persona, he won the second round with $55 \%$ of the popular vote, while Fernando Haddad, a progressive political scientist, former mayor of São Paulo, and Lula's hand-picked successor as leader of the Workers' Party (PT), captured $45 \%$. Haddad's showing in the second round nonetheless exceeded expectations, given the fact that he entered the race so late in the day. The PT took a very long time to come to grips with the fact that Lula would remain in prison and could not ultimately sustain his candidacy. Partially as a result of this overdue embarkation, Haddad secured only $29 \%$ of the vote in the first round. ${ }^{2}$

In an unexpected boon to Bolsonaro's campaign, he was stabbed in early September at a campaign rally by a mentally disturbed man. The notably inarticulate candidate for the PSL was thereafter able to avoid all scheduled debates with opponents. Instead, he tweeted directly to his followers over an extended convalescence. Meanwhile, Haddad raced around the country, speaking at endless events, in an attempt to make up for lost time. ${ }^{3}$ Following Bolsonaro's late surge in the polls and surprisingly robust finish in the first round, the representative bodies of domestic and international capital, as well as their mouthpieces in the mainstream media, abandoned their traditional parties and rallied behind him to thwart any chance of the PT resuming office.

Bolsonaro, as Perry Anderson notes, 'took every state outside the northeastern redoubt of the PT; every major city in the country; every social class with the exception of the very worst off, living on incomes of less than two minimum wages; every age group; and both sexes - only among the cohort between 18 and 24 did he fail to win a majority of women's votes.' And yet, while the enthusiastic right-wing core of his support base celebrated with frenzy in the streets at the results,

there had been no great rush to the polls. Voting is compulsory in Brazil, but close to a third of the electorate -42 million voters - opted out, the highest proportion in twenty years. The number of spoiled ballots was

1 Thanks to Sean Purdy and Daniela Mussi for their assistance during fieldwork in São Paulo and Rio de Janeiro and for their comments on this piece. I also benefitted from conversations with Benjamin Fogel in São Paulo. Thanks also to Todd Gordon, Adam Hanieh, Joe Hayns and Forrest Hylton for reading an earlier draft.

2 Mussi and Bianchi 2018, p. 351.

3 Phillips 2018a. 
6o percent higher than in 2014. A few days earlier, an opinion poll asked voters their state of mind: 72 percent replied 'despondent,' 74 percent 'sad,' 81 percent 'insecure.' 4

Boundless disillusion in the PT was one important factor in the forlorn societal condition which ultimately sanctioned the rise of a grotesque to the presidency.

Part of a wider implosion of the political centre in many of the world's ailing liberal democracies since the onset of the Great Recession in 2008, the Brazilian elections witnessed the utter routing of capital's preferred candidate, Geraldo Alckmin, who ran for the Party of Brazilian Social Democracy (PSDB), the traditional representative of international capital and the party most associated with neoliberal restructuring. Likewise, the other long-established party of the centre-right, the Brazilian Democratic Movement Party (РMDB), under the leadership of Henrique Meirelles, was annihilated. On the centre-left, the PT accelerated its decline, which began as early as 2014, although it retained its position as biggest party in the lower house of congress, and won four state governorships. The Brazilian Communist Party (РСB) did not even receive a sufficient number of votes to allow access to public resources and television airtime, and the same was true of the campaign by environmentalist Marina Silva of the Sustainability Network (REDE). ${ }^{5}$

Brazil's open-list proportional representation system has long been characterised by hyper-fragmentation in the two houses of congress, and a form of rule commonly known as 'coalition-presidentialism', whereby the centralised power of the executive must be coordinated with a decentralised and fragmented legislature. The consequent methods of rule typically involve the president gifting cabinet positions and other benefits to an array of small parties in congress in order to ensure a governable coalition. ${ }^{6}$ The congressional results in the October 2018 contest, which ran parallel to the presidential ballot, heightened the traditional centrifugal scattering of micro-parties, and made visceral the collapse of the political centre. In the most splintered congress in Brazilian history, with over 30 parties finding representation, Bolsonaro's PSL rose from 8 to $5^{2}$ seats in the 513 -seat Chamber of Deputies, while, as noted, the PT remained the biggest party in this domain, with 56 , but was still down 13 from its previous position. As a whole, centre-right and right parties loosely aligned with Bolsonaro's PSL dominate the lower house, and by one credible

4 P. Anderson 2019.

5 Grigera, Webber, Abilio, Antunes, Badaró Mattos, Fernandes, Nunes, Paulani and Purdy 2019.

6 Fogel 2018. 
measure right-wing representatives in the lower house rose from 190 in 2010 to 301 in 2018. In another reflection of the pervasive sentiment of anti-politics in the country, voters rallied to perceived outsiders, with the traditional PSDB and PMDB's congressional representation halved, and more than 53 per cent of seats in the Chamber of Deputies seized by newcomers. Likewise, in the Senate, while 32 incumbents ran for re-election, only eight were successful. ${ }^{7}$

How to assess the new Brazilian regime? Now one year in to Bolsonaro's rule, some broad-stroke preliminaries are possible. In what follows I trace the political paralysis of the first several months, the popular social base of Bolsonarismo, its relationship to capital, and the role of evangelical Pentecostalism. I offer a biographical profile of Bolsonaro himself, map the three pivotal factions constituting the new government, and assess the economic outlook of the country. To anticipate the basic conclusions: the Bolsonaro regime is a weak and internally divided far-right regime, with declining popular support; capital backed Bolsonaro as a way out of crisis, but thus far the regime has not delivered, and the markets are losing faith.

\section{Manic Stasis}

Bolsonaro's first several months in office were characterised by misrule and pandemonium - endless Twitter wars; racist, sexist, and homophobic tirades; international diplomatic dramas; corruption scandals; cabinet instability; feuds with the legislature and judiciary; attempts to officially reimagine the 1964-85 dictatorship as a golden period of democratic rule; and generalised policy paralysis. ${ }^{8}$ But until mass mobilisations around education cuts in May 2019, and a general strike in mid-June of the same year, this had decidedly not been a result of strong left-wing opposition, whether in congress or in the streets, but rather an outgrowth of internal wrangling between the constitutive factions of the tripartite coalition undergirding the regime - cultural authoritarians, militarists, and neoliberal technocrats. ${ }^{9}$

Each week there is further haemorrhaging of popular support for the president. According to a poll from April 7, 2019, conducted by the polling firm Datafolha, Bolsonaro registered the worst approval ratings after three months in office of any elected president in a first term since democracy was restored

\footnotetext{
$7 \quad$ Schipani and Leahy 2018; Mussi and Bianchi 2018; P. Anderson 2019.

$8 \quad$ Londoño and Casado 2019; Uribe and Fernandes 2019; Fogel 2019a.

$9 \quad$ On the education demonstrations, see Redden 2019; Nunes 2019; Escobar 2019; Phillips 2019. On the general strike, see Jornal do Brasil 2019.
} 
in $1985.30 \%$ of Brazilians considered his government to be bad or terrible, $32 \%$ optimal or good, and $33 \%$ average..$^{10}$ By contrast, for the equivalent period in office during their first terms, the disapproval ratings for former presidents Fernando Collor, Fernando Henrique Cardoso, Luiz Inácio Lula da Silva, and Dilma Rousseff were 19, 16, 19, and 7, respectively.11 All the same, Collor was eventually impeached, Lula imprisoned, and Dilma thrown out of office by an institutional coup d'état.

Dangers lurk everywhere in the ensuing ataxia of the Brazilian body politic. 'There is an atmosphere of pervasive violence in the country, which may be the way in which this administration tries to support itself, through a growth in organised and disorganised violence', the political economist Alfredo Saad-Filho suggested in a public conversation we held in early March 2019 at Goldsmiths, University of London.

But other than this, it is a circus of horrors, absolutely disorganised. Which may be a good thing for the left, in the long term. Because as they are fighting amongst themselves, they are not doing horrible things to everyone else. But I think this is a very small consolation. The political programme of this government is intrinsically and heavily destructive of citizenship, of collectivity, of any form of social cohesion. There is absolutely nothing good associated with the social forces supporting Bolsonaro. It is an absolute political tragedy, and the left, still, is completely disorganised. ${ }^{12}$

What do we know of the social composition of Bolsonaro's mass base? What of his relations to capital? One pithy phrase, 'the bull, bullet, and bible' bloc, captures part of the picture, insofar as it highlights the centrality of agribusiness, the arms industry, and religious conservatism. ${ }^{13}$ Agribusiness, ideologically attracted to Bolsonaro's vision of freeing-up access to weapons and criminalising rural workers' movements, rallied particularly effectively to Bolsonaro in the south and central-west of the country. ${ }^{14}$ Finance and large

\footnotetext{
$10 \quad$ Folha de São Paulo 2019a.

11 Uribe and Fernandes 2019.

12 Political Economy Research Centre (PERC) 2019.

13 Schipani and Leahy 2018.

14 Garcia 2019.
} 
domestic industrial capital backed Bolsonaro only late in his campaign, after Alckmin failed to gain traction with the electorate, and other 'outsider' names were trialled without success. It was Bolsonaro's move to bring on board neoclassical economist Paulo Guedes that eventually secured their backing. This was also true of Wall Street and international financial markets more generally, who were finally convinced that Guedes would ensure 'the necessary reforms and privatization of the last state-owned companies, such as Petrobras'. ${ }^{15}$ Ultimately overcoming their doubts in Bolsonaro, and fearing victory of the PT in the second round above all else, 'every single business association, at every level, supported Bolsonaro. Every single business person who appeared on the media supported the right.'16

On a more general scale, the demographic with the most confidence in the present administration is evangelical and male, with above-average educational attainment, earning more than five times the minimum wage, and living in the south of the country. ${ }^{17}$ This is the voter profile most attracted to the ideological signifiers of lava jatismo (anti-corruption), antipetismo (antipathy toward the PT), anti-politics, 'traditional' moral values, and the promise of 'law and order.'18 The upper orders of Brazil's urban metropoles have cultivated a particularly stark class resentment of the modest redistributive gains of the PT era - annual minimum-wage increases, expansion of access to higher education, social and racial quotas, improvements in the labour code for domestic workers, the priming of cash-transfer programmes such as Bolsa Família, and increases in public resources for the impoverished strata of the poorest regions in the north and northeast. That these measures granted a novel quotidian presence of Afro-Brazilians and working-class citizens in the heretofore exclusive spatial domains of the rich and the white - shopping malls, universities, and aeroplanes - was an affront to an elite way of life, a powerful psychosocial component of upper middle-class support for Bolsonaro. ${ }^{19}$

Such ressentiment possibly runs even deeper among the lower middle classes, who enjoyed improved access to consumption, university, and formal employment in the high era of the PT (2003-12), but who have since watched these material gains evaporate, along with their social privileges, as a consequence of economic meltdown. ${ }^{20}$ Some have ended up as deeply precarious and indebted workers, the canonical Uber drivers and cosmetics saleswomen,

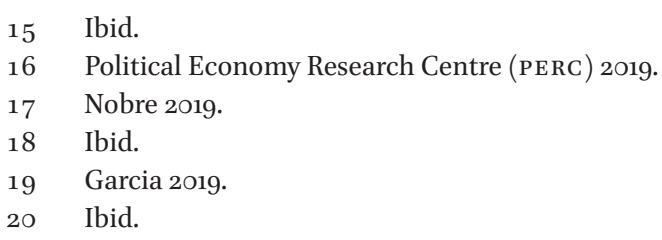


among whom an anti-politics of bitterness is directed principally toward the PT, and increasingly finds combination with animus for feminists, LGBTQ+ people, and leftists. ${ }^{21}$ Joining the downwardly mobile lower-middle-classesturned-precarious-workers in their support for Bolsonaro is a petit-bourgeois layer of commercial retailers and liberal professionals - doctors, lawyers, engineers, and the like - with a shared animosity for taxes and state provision of social rights. ${ }^{22}$ Intermediate tiers of the social structure gravitated to Bolsonaro in large numbers, while capital cohered behind him as a last route out of crisis.

\section{$3 \quad$ Evangelism}

But there remains a missing element in this sociological audit. Indeed, one of the most critical combustible elements in Brazilian society, the political consequences of which are only understandable in relation to labour-market transformations and capitalist crisis, has been the monumental rise of evangelical Pentecostalism. Though raised a Catholic, Bolsonaro inaugurated his public dalliance with evangelism on 12 May 2016. Dressed in white, he was filmed being baptised in the River Jordan - where, according to the Bible, Jesus himself was baptised - by a Brazilian evangelical pastor of the Assembly of God. ${ }^{23}$ Even so, the current president identified himself at the time as Catholic, and has never since renounced his faith. ${ }^{24}$ His adult sons are evangelicals, as is his third and present wife, Michelle Bolsonaro, a sign-language interpreter who plies her trade in Pentecostal circles. The president's last wedding was officiated by the influential pastor Silas Malafia, also of the Assembly of God. Travelling in these intimate cliques, Bolsonaro has managed to sustain a popular ambiguity as to his Catholic-evangelical identity, a not-inconsequential political advantage. ${ }^{25}$

In his first public appearance following victory in October 2018, Bolsonaro participated in a televised evangelical sermon, conducted by pastor and exsenator Magno Malta; it was transmitted to millions of Brazilian television screens. ${ }^{26}$ In Bolsonaro, evangelicals have found a spokesperson, even while he continues to enjoy the support of the most conservative wing of Catholic society, signalled, for example, by the devotion to the president of archbishop

\footnotetext{
21 Ibid.

22 Braga and Purdy 2019.

23 Oualalou 2019, p. 68.

24 Ibid.

25 Oualalou 2019, p. 69.

26 Ibid.
} 
of Rio de Janeiro, Orani João Tempesta. ${ }^{27}$ Similarly, while the current president is embraced as more or less evangelical by the evangelicals, his chameleon religiosity has allowed him to circumnavigate the ordinary disdain for evangelism found in the most privileged and well-educated strata of Brazilian society. ${ }^{28}$

The difference separating Bolsonaro and Haddad was 10.76 million votes. ${ }^{29}$ Roughly $56 \%$ of the electorate is Catholic, $30 \%$ evangelical, $7 \%$ non-religious, and $1 \%$ a composite of Afro-Brazilian religions. In the event, the Catholic vote was divided across the candidates, with a slight advantage going to Bolsonaro. Haddad drew more concentrated support than Bolsonaro from the numerically insignificant affiliates of Afro-Brazilian religions, as well as the non-religious. ${ }^{30}$ Crucially, the evangelicals acted as a bloc as never before, with their leaders harvesting years of dedicated political organising. Although evangelicals represent less than a third of the electorate, they delivered 11 million votes to Bolsonaro, more than the difference separating him from Haddad. ${ }^{31}$

Despite a formal separation of church and state in the constitution of 1891 - further institutionalised in the declaration of the republic in 1899 Catholicism has been the overwhelmingly dominant religion of Brazil, as well as being intricately bound up in the common-sense notions of the Brazilian nation. Over the last few decades, however, this hegemony has suffered a relative decline, with a religious shift to evangelical Pentecostalism. ${ }^{32}$ One authoritative account points to three dominant waves of Pentecostalism in the country. The first stretched from 1910 to 1950, during which time the Assembly of God, the Christian Congregation, and the International Church of the Four Square Gospel were established. These now constitute Brazil's classic Pentecostal churches, and are distinguished by their emphasis on the gifts of the Holy Spirit and the ritual of speaking in tongues. ${ }^{33} \mathrm{~A}$ second wave, beginning in $195^{\circ}$ and closing in 1970, inducted a period of popular evangelism, with the first inroads into the communicative networks of radio and television. American televangelism was the model of this phase, with the Brazil for Christ Church and God is Love Church its quintessential institutional expressions. ${ }^{34}$

\footnotetext{
27 Oualalou 2019, p. 72.

28 Oualalou 2019, p. 76.

29 Oualalou 2019, p. 69.

30 Ibid.

31 Oualalou 2019, p. 70.

$32 \quad$ Oro and Tadvald 2019, p. 56.

33 Oro and Tadvald 2019, p. 57.

34 Ibid.
} 
The last wave began when the second ended, and extends into the present. It is sometimes known as 'neo-Pentecostalism'. An early entrant was the Universal Church of the Kingdom of God, established in 1977 by Edir Macedo, joined shortly thereafter by the International Grace of God Church, Reborn in Christ Church, Worldwide Church of God's Power, and the evangelical community of Sara Nossa Terra. Driven by a new managerial ethos which structures religious institutions on the model of corporations, neo-Pentecostalism is doctrinally associated with the theologies of spiritual warfare and prosperity intimately related to one another. ${ }^{35}$

Originating in American evangelical milieus during the later period of Jimmy Carter's presidency and the contemporaneous ascendancy of Ronald Reagan, these two theologies found a syncretic synthesis in their new Brazilian home. The 'theology of prosperity' advances the view that God created his children to be prosperous and to obtain happiness in this earthly world. In other words, God wants to distribute wealth and good health to those who fear him in the here and now. To guarantee earthly prosperity one needs to demonstrate one's faith, which entails financial offerings to the church. For adherents of the theology of prosperity there is a correspondence between the strength of faith and the size of these offerings. ${ }^{36}$ Unsurprisingly, the most successful evangelical organisations in Brazil are quasi-financial, multi-million-dollar enterprises as a result. Prosperity, in the sense of this religious creed, celebrates the pursuit of personal enrichment, and implicitly casts aspersions on the poor, whose poverty is traceable to personal failings. A stratagem of individual survival in the face of a protracted precariousness at the heart of the socio-economic order nicely complements a wider deterioration of collective subjectivity in Brazilian society, and the decades-long construction of neoliberal subjects, something that was never surpassed during the PT interregnum.

The theology of spiritual warfare, meanwhile, involves a belief that the world is a staging ground for unadorned confrontation between forces of good and evil. According to its postulates, the forces of evil seize hold of the faithful and are the root cause of their problems and tragedies. Exorcism, therefore, to be carried out by religious leaders, is a necessary measure to expel the demons from the faithful and thus ensure their prosperity and health. Freedom from demons becomes a natural prerequisite for wealth and earthly happiness. ${ }^{37}$

\begin{tabular}{ll}
\hline 35 & Ibid. \\
36 & Ibid. \\
37 & Ibid.
\end{tabular}


TABLE 1 National Census: Percentage of Catholics and Evangelicals, 1980-2010

\begin{tabular}{lccll}
\hline & Census 1980 & Census 1991 & Census 2000 & Census 2010 \\
\hline Catholics & 89.2 & $83 \cdot 3$ & $73 \cdot 7$ & 64.6 \\
Evangelicals & 6.6 & 9 & 15.4 & 22.2 \\
\hline
\end{tabular}

SOURCE: ORO AND TADVALD 2019, P. 59.

A national census is held every decade in Brazil, with the next one due in $2020 .{ }^{38}$ Table 1 indicates patterns of religious self-identification, with a sharp decline of Catholics from 89.2 to $64.6 \%$ of the population from 1980 to 2010 , and an attendant increase in evangelicals from 6.6 to $22.2 \%$ over the same period. If we parse the category of 'evangelical' further, it is possible to identify over half as neo-Pentecostals ( $13.3 \%$ of the total population), with the historical Pentecostals (Lutherans, Presbyterians, Baptists, and so on) representing only $4 \%$ of the total, and seemingly in stagnation in demographic terms, and the remaining $4.8 \%$ a series of indeterminate evangelical sects (more independent, with less denominational fidelity). ${ }^{39}$ The Assembly of God remains the biggest single institutional expression of evangelism in the country, with 12.3 million followers. ${ }^{40}$

While lacking the empirical depth and range of national censuses, individual studies by specialists in the area hypothesise that the rate of Catholic decline and evangelical uptick is increasing. Between 1990 and 2010, the Catholic population was losing adherents at the rate of $1 \%$ per year, while evangelicals were moving in the other direction at a rate of $0.7 \%$. The latest specialist analyses suggest that the annual rate of diminution in Catholicism has accelerated to $1.2 \%$ since 2010 , and the annual rate of gains for evangelism has moved in the opposite direction at $0.8 \%$. If these numbers are roughly correct, Catholics will represent fewer than half of the population by 2022. ${ }^{41}$

As noted, there was a strong correlation between evangelical adherence and votes for Bolsonaro. In the states with the strongest evangelical

38 The government has warned that it will be scaling down the scope of the census, eliminating crucial questions such as those concerning unemployment. There have already been staff cuts at the Brazilian Institute of Geography and Statistics, which is the entity responsible for carrying out the census. As a result, there have been protests by census employees. See Esquerda Diário 2019.

39 Oro and Tadvald 2019, p. 6o.

40 Ibid.

41 Oualalou 2019, p. 70. 
presence - Rondônia, Roraima, Acre, and Rio de Janeiro - Bolsonaro was handed spectacular victories, and in the states of the northeast, where evangelicals have their weakest base, Haddad won handily. This is not to argue, of course, that religion was the only determining factor in far-right growth, but it is to point out its contingent decisiveness in the October electoral contest. ${ }^{42}$

Haddad made a perfect scapegoat for organised evangelical reaction once he was finally declared the PT presidential candidate. When Haddad was minister of education during Rousseff's first term in office, he attempted to introduce educational materials to combat homophobia in the public school system. Pastor Silas Malafia, in an exemplary response from the evangelical right, denounced the materials as a 'gay kit', designed to convert children into homosexuals. ${ }^{43}$ It was then-congressperson Jair Bolsonaro who took it upon himself to hold up the 'gay kit' as the empyrean of the PT's moral depravity. Come the 2018 electoral season, Bolsonaro unleashed a tribe of social-media combatants, generating a tidal wave of fake-news memes, including images of babies being fed in public day-care centres of the PT era with bottles shaped as penises. ${ }^{44}$

While Bolsonaro seemed, to many, to have simply materialised out of the ether when he assumed the presidency, in a certain sense the 2016 municipal elections in Rio were a premonition of things to come. While evangelicals had long had a presence in the state of Rio de Janeiro, Brazil's second largest city, the state capital and home of Carnival, had historically been seen as hostile territory for traditional mores and conservative religious etiquette. And yet, Marcelo Crivella, a bishop of the Universal Church and nephew of Edir Macedo, attracted voters behind a platform of antipetismo, a war on 'gender ideology', and a conservatising agenda for the public-school system - depicted as a hotbed of cultural Marxism and social decadence. He successfully seized the mayoralty of Rio. ${ }^{45} \mathrm{All}$ of this is a frightening intimation of just how quickly the extreme right can germinate when the soil shifts.

Ruy Braga, one of Brazil's most innovative and perceptive sociologists of labour, has written the most penetrating early mapping of the complex relations between evangelism and alterations in the political subjectivity of specific subaltern layers, corresponding to the informalisation of the world of work, contradictions within the PT's development model, and the dynamics

\footnotetext{
42 Oualalou 2019, p. 71 .

43 Ibid.

44 Ibid.

45 Oualalou 2019, p. 75 .
} 
of economic crisis over the last several years. ${ }^{46}$ The critical puzzle Braga poses is why 'a substantial part of the working class chose a candidate clearly opposed to a redistribution agenda and who promised an attack on social security and labour rights?'47 Conservative evangelism is definitely part of the story, but it needs to be linked, in Braga's view, to the changing sociological conditions of a specific layer of the population - a working-class layer accounting for more than a third of the electorate - which receives between two and five times the minimum wage; that is, impoverished workers, but not the poorest of the poor. This bracket of society used to vote consistently PT, but in 2018, $61 \%$ voted Bolsonaro, and only $39 \%$ for Haddad. The poorest, by contrast, persisted in their alignment with the PT. 'We can infer, then,' Braga suggests, 'that the changing loyalties of those who receive between two and five minimum wages ... is what explains the election of the PSL candidate. 48

There is some merit in André Singer and Gustavo Venturi's argument that low-income supporters of Bolsonaro were motivated by a concern for public safety, and were persuaded by his promise of a tough line on crime. ${ }^{49}$ For Braga, this perspective is compelling insofar as it identifies 'social violence as a trigger for Bolsonarism among people whose family incomes range from two to five minimum wages', but to stop here would be to remain on the surface of appearances, and to miss a much more thoroughgoing set of underlying structural variables. ${ }^{50}$ If public safety was a proximate trigger, in other words, 'the profound cause was the global tendency of frustration, particularly among precarious and informal workers living in large urban centers, with the limits (political, economic, and ethical) of the mode of development championed by former PT president Lula da Silva. ${ }^{51}$

The PT development project at its peak (2003-12) was a distributionist model rooted in an unstable class compromise, as capital continued to profit handsomely and social-movement leaders were increasingly pacified through incorporation into the state. ${ }^{52}$ Lula introduced distributive elements to the mode of rule, while maintaining a broad allegiance to the various sections of capital - agribusiness, finance, industrial, and the frequent symbiosis of the latter two. Honing a regime of multiclass conciliation, he conceded to the demands of capital while offering targeted welfare to pauperised

$\begin{array}{ll}46 & \text { Braga 2012 and 2017. } \\ 47 & \text { Braga 2019. } \\ 48 & \text { Ibid. } \\ 49 & \text { Singer and Venturi 2019. } \\ 50 & \text { Braga 2019. } \\ 5^{1} & \text { Ibid. } \\ 5^{2} & \text { Ibid. }\end{array}$


strata dependent on the state for survival, most famously through the World Bank-lauded Bolsa Família - a conditional cash-transfer programme that reached millions. ${ }^{53}$ Higher education was expanded and university quotas were introduced for black students. ${ }^{54}$ Millions of jobs were created, although these were mainly low-paid, unskilled and precarious. The state invested in state-owned enterprises, particularly through the expansion of Petrobras activities in 2009, following the company's discovery of deep-sea reserves in the Atlantic. ${ }^{55}$ Expansionary policies were introduced in 2009-10 in the wake of the global crisis, drawing on foreign reserves that had been accumulated at high rates during the commodities boom.

Throughout the boom years, the PT was capable of lubricating its multiclass alliance, targeting modest social reforms at the poorest, providing employment, and raising the minimum wage and living standards, all the while allowing the rich to capture a disproportionate share of the wealth being accumulated. At the same time, under the second Lula administration there was no diversification of exports, the technological content of manufacturing production remained the same, and infrastructural investment, including basic urban services of transport and water - flashpoints in coming protests - was severely neglected. ${ }^{56}$ Critical to the transformation in political subjectivity among those earning between two and five times the minimum wage was the combination of poor jobs, urban infrastructural decrepitude, and accelerating personal indebtedness. Between 2005 and 2015, 'total debt owned by the private sector increased from 43 to 93 percent of GDP', Anderson points out,

with consumer loans running at double the level of neighbouring countries. By the time Dilma was re-elected in late 2014, interest payments on household credit were absorbing more than a fifth of average disposable income. Along with the exhaustion of the commodity boom, the consumer spree was no longer sustainable. The two motors of growth had stalled. ${ }^{57}$

Braga’s ethnographic work among call-centre workers in São Paulo reveals how the growing expectations of social mobility, fuelled in part by the PT's ideological commitment to expanding a 'new middle class', proved unsustainable.

\footnotetext{
53 Antunes 2015.

54 Saad-Filho 2016.

55 Saad-Filho and Boito 2015, pp. 217-18.

56 Saad-Filho and Boito 2015, p. 218.

57 P. Anderson 2016.
} 
Consumption increased significantly, but it did so through the snowballing indebtedness of working-class layers of the population. As workers became indebted they were more likely to see the short-lived improvements in livelihoods as a product of their own efforts, rather than as a consequence of PT social programmes or economic policies. ${ }^{58}$ When the economic crisis began to pinch in 2013, these livelihood gains for many informalised workers disappeared and they became embittered by targeted social programmes like Bolsa Família and university racial quotas, from which they never directly benefited. Priced out of urban residential centres, they moved further and further into the distant suburbs, and their everyday experiences were mired in multi-hour commutes, a direct outgrowth of the neglect of public-transport infrastructure under the PT.

Informal workers of this strata became ever more susceptible to right-wing formulations which identified such programmes as responsible for reproducing the ostensible laziness of welfare recipients, on the one hand, and the corruption of the political clientelism of the PT's rule, on the other. 'The Brazilian far-right managed to instrumentalize this feeling through the rhetoric of "meritocracy", appealing to popular resentment against the PT as the crisis deepened and decimated outskirts of cities, becoming increasingly dependent on notoriously inefficient public services. ${ }^{59}$ While social progress for subaltern layers was real under the PT, it was also always double-sided. Consumption was accompanied by indebtedness, housing ownership by longer commutes, and employment by precariousness. ${ }^{60}$

All the same, popular strata maintained their loyalty to the PT until Dilma's second term, when Brazilian society's shift to the right rapidly intensified in a distorted response to the hard neoliberal turn on the part of the government and the stark worsening of the recession in 2015 and $2016 .^{61}$ The decline of labour-union density and militancy under the PT, and the rise of outsourcing, cooperative work and self-employment, helped to usher in a replacement of collective identities rooted in working-class responses to shared interests with individualist identities and survival strategies. What sociologist Alan Sears has called the 'infrastructure of dissent' suffered protracted diminution, and in its place a neo-Pentecostal infrastructure flourished. ${ }^{62}$ Health and other socialassistance programmes in the suburbs of São Paulo came to be administered

\footnotetext{
$5^{8} \quad$ Braga 2019.

59 Ibid.

6o Ibid

61 Ibid.

62 Sears 2014.
} 
by evangelical churches, even while being financed by the federal government. It was evangelism that came to be seen as serving the downwardly mobile informal working-class layers, while the PT became associated with neglect and corruption. ${ }^{63}$

The 'neo-Pentecostal movement today flourishes in a context of dismantling of labour protections, strengthening in low-income groups a subjectivity clearly aligned with the model of neoliberal self-management', Braga argues. 'The mediation between the worker and the world of work ceases to be predominantly collective and begins to take refuge in the formulas of popular entrepreneurship.' ${ }^{64}$ As we have seen, the 'theology of prosperity' neatly aligns with such individual survival strategies. With the exacerbation of informality, unemployment and underemployment, it is unsurprising that small shop owners and more-established street vendors now vie competitively with a burgeoning layer of newcomer street vendors in Brazil's major urban centres. They grow to fundamentally resent each other, while uniting in their hatred of lumpen - the thieves and drug addicts. Meanwhile, all of the lower orders become more exposed to violent crime in a decaying social order. ${ }^{65}$ In Brazil's new world of work, "politicized collective relationships like those of the trade union movement are weakened in favour of competitive relations linked to the occupation of sales areas, as well as by the growing fear of urban violence.... If trade unionists have become distant from the everyday lives of subaltern classes, becoming less important to informal workers, it is relatively easy for a farright candidate to associate them, for example, [with] the corrupt schemes of a political system in crisis, including them in the group of "good-for-nothings" who are "destroying the country".66 For processes comparable to those at work in Brazil today, one need only look to the best ethnographies of workingclass decomposition and the rise of far-rights in Colombia and Guatemala in recent decades. ${ }^{67}$

In the 2018 elections, the vast, well-financed, and expanding reactionary fabric of evangelical Pentecostalism - temples, websites, television and radio stations - mobilised the novel political subjectivities of those earning between two and five times the minimum wage, and helped transform them into Bolsonaro's foot soldiers. ${ }^{68}$

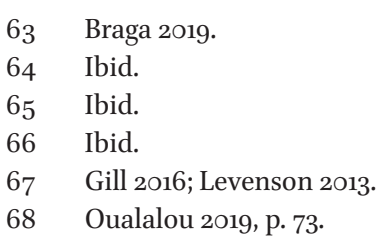


Who is Jair Bolsonaro? With good reason, he is often set side by side with contemporaries like Viktor Orbán of Hungary, Jarosław Kaczyński of Poland, Narendra Modi of India, Recep Tayyip Erdoğan of Turkey, Rodrigo Duterte of the Philippines, or Donald Trump of the United States. He is also occasionally discussed alongside an earlier generation of authoritarian Latin American leaders, such as Augusto Pinochet of Chile, or Jorge Rafael Videla of Argentina, alerting us to the potential menace of a return to a darker era - inconceivable until recently to many liberal social-scientific analysts of Latin America, comforted in their echo chambers by assurances that the region's democracies had been resolutely 'consolidated'.

In some ways, though, the most analogous figure to Bolsonaro is the Guatemalan génocidaire Efraín Ríos Montt of the early 1980s, whose evangelical Pentecostalism 'sustained a vision of a new Guatemala, formed from a potent mix of religion, racism, security, nationalism, and capitalism'. 69 'Brazil, in truth, elected a politician much more extreme than the other new authoritarian leaders', according to left-liberal Brazilian critic Celso Rocha de Barros. 'Bolsonaro is the most radical subject to occupy the presidency of any democratic country in the contemporary world. ${ }^{\prime 70}$ Whether Bolsonaro is more extreme than Duterte, or Modi for that matter, is open to debate, but they are at least ultra-ists of a similar genre.

In a remarkable essay on the political culture of classical fascism, the historian Jairus Banaji explains that 'fascist ideology is actually only a pastiche of motifs, it is a pastiche of different ideological currents, it has very little coherence on its own. ${ }^{71}$ In a comparable eclecticism, even if there has not been a fascist dictatorship installed in Brazil, Bolsonaro's Weltanschauung revolves mainly around conspiracy, the political left, women, black and indigenous people, LGBTQ+, and environmentalists. He has famously explained that he would be incapable of loving a homosexual son, and that he would rather such a son die in an accident than survive while gay. ${ }^{72}$

For Banaji, drawing on the work of Wilhelm Reich, patriarchal relations and the authoritarian family are at the root of the state's power in capitalist society. The authoritarian family, in this sense, "is a veritable "factory" of reactionary ideology', finding its fullest expression under fascism, 'where this relationship

\footnotetext{
69 Traverso 2019, p. 171.

$70 \quad$ Rocha de Barros 2019.

71 Banaji 2017.

72 J.L. Anderson 2019.
} 
between the two becomes overtly posited.' There is a fundamental 'resonance between the authoritarian character-structures that are moulded inside the patriarchal family and the Führer ideology which is characteristic of all rightwing mass movements.' ${ }^{73}$ Bolsonaro's unfettered attacks on 'gender ideology' recall Reich's insight, in that they grant wholesale permission to unleash the worst strains of gendered violence already extant in the interstices of Brazilian society. 'Rape is as common as murder in Brazil', Anderson reports, 'more than sixty thousand a year, around 175 a day - the number reported has doubled in the last five years. ${ }^{74}$ Queer Brazilians have likewise been subject to unmitigated savagery. Already facing the highest level of lethal violence against queer people in the world, with 455 reported murders in 2017 , the presidential election race of 2018 witnessed roughly 50 attacks 'directly linked to Bolsonaro's supporters; among them were at least two incidents in which trans women were killed by men who invoked his name. ${ }^{75}$

During his seven forgettable terms in the Chamber of Deputies, Bolsonaro's main interventions turned on restoring the good memory of the military dictatorship. If anything, on this view, the dictatorship had not gone far enough in its notorious rounds of execution and torture of dissidents and activists. During the impeachment of Rousseff, Bolsonaro employed his speaking time to explain he was pledging his vote in the name of Carlos Alberto Brilhante Ustra, head of the Doi-Codi unit responsible for the personal torture of the former PT president when she was captured during her period of guerrilla militancy against the dictatorship.

Bolsonaro has denounced fellow deputy Maria do Rosário, also of the PT, as 'not worth raping'. He has called immigrants 'scum'. The United Nations is for him a 'bunch of Communists'. A vociferous supporter of the military police and death squads, or militias, that specialise in the racist terrorisation of the favelas in his beloved Rio, Bolsonaro has said that a 'policeman who doesn't kill, isn't a policeman. ${ }^{\text {'6 }}$ His inaugural address as president pledged to 'rescue the family, respect religions and our Judeo-Christian tradition, combat gender ideology, conserve our values'. Bolsonaro has referred to quilombolas, descendants of runaway slaves who have a distinct legal and cultural status in Brazil, as obese and lazy: 'They don't do anything. They don't serve even to procreate anymore. ${ }^{77}$

$\begin{array}{ll}73 & \text { Banaji 2017. } \\ 74 & \text { P. Anderson 2019. } \\ 75 & \text { J.L. Anderson 2019. } \\ 76 & \text { Ibid. } \\ 77 & \text { Ibid. }\end{array}$


It is worthwhile to recall here Alberto Toscano's penetrating observations on 'capitalist folklore', and specifically the notion that 'fascistic, authoritarian and right populist solutions do not require a unified conception of the world and of life; or rather that, in Fredric Jameson's terms, they can operate with the most degraded varieties of "cognitive mapping," with the image of "totality as conspiracy." If the illusion of the (left) intellectual is that [quoting Stuart Hall] "ideology must be coherent, every bit of it fitting together, like a philosophical investigation," this is an illusion that the right (especially once it leaves behind the rigor and asceticism of high bourgeois culture) need not entertain, happily flaunting its programmatic incoherence and rejection of the rationalist demand that politics have a logic, crafting its discourse to appeal in incommensurate ways to contradictory audiences. 78

Olavo de Carvalho is the quintessence of degraded cognition of this kind. He is to Bolsonaro what Steve Bannon was to Trump before their falling out. A Brazilian, but resident of Richmond, Virginia since 2005, Carvalho is a bizarre 'autodidact, philosopher and former astrologer', with a social-media audience of more than 570,000 and sufficient influence within the president's most intimate coterie to determine cabinet selection and structure the ideological content of much of the president's bountiful Twitter output. ${ }^{79}$ Carvalho 'has claimed that Pepsi is sweetened with the cells of aborted foetuses; that legalizing same-sex marriage leads to legalizing pedophilia; and that calamitous natural disasters such as Hurricane Katrina and the 2011 earthquake in Haiti may be divine punishment for practicing African religious traditions.' ${ }^{\prime} 0$ For Carvalho, 'Brazil's problem with violent crime might have been averted if the military regime had killed the right twenty thousand people.81 A recurring theme in the YouTube repertoire of the 72-year-old, pipe-smoking bear-hunter 'is a neo-Marxist insistence on the cultural hegemony that he claims has been imposed by globalists, the left, and the politically correct via schools, political parties, and the mainstream media and "fake news". 82 'Cultural Marxism' has befouled the West, not least in the way it has concocted the elaborate ruse of climate change.

Channelling Carvalho's worldview into the institution of the Brazilian presidency, Bolsonaro 'has been able to capitalize on the anti-political sentiments and deep conservatism prevalent among sections of Brazilian society',

\footnotetext{
78 Toscano 2019 .

79 Rathbone 2019.

80 Londoño and Casado 2019.

81 J.L. Anderson 2019.

82 Ibid.
} 
according to historian Benjamin Fogel. 'His politics are premised on capital punishment for criminals, racism, sexism, homophobia, nostalgia for military dictatorship, gun ownership, pro-life views, and virulent anti-leftism, all combined with a dose of neoliberalism. Bolsonaro has been able to ride the anti-leftism wave unleashed by anti-corruption protests to pose as a political outsider capable of renewing the broken political system and a morally degenerate society.' 83

As of June 2019, Bolsonaro had 9.5 million followers on Facebook, twice that of the country's most important newspaper. By some estimates, he has 3.4 million Twitter subscribers. ${ }^{84}$ Lacking a party structure from which to mobilise his core supporters and maintain their fervour, Bolsonaro depends on the extemporaneity of unmediated social-media relations. As Toscano has stressed elsewhere, summoning Theodor Adorno, there is always 'the problem of the libidinal bond that fascism requires, both vertically towards the leader (especially in the guise of a kind of play of narcissisms, the follower finding himself reflected in the leader's own self-absorption) and horizontally, towards the racialized kin or comrade, identifying this as a technical, or psycho-technical, problem for fascism itself.... This libidinal energy is of necessity personalized as an "erotic tie" (in Freud's terms), and operates through the psychoanalytic mechanism of identification (again, both horizontally and vertically). ${ }^{85}$

Prolonged degeneration of political representation in Brazil, a pronounced disintegration of political institutionality, has helped to fertilise Bolsonaro's efflorescence. Outside of party structures, and drawing on the novel identifications allowed by social-media interaction, Bolsonaro has harvested the libidinal bonds forged with his core supporters - roughly 30 per cent of the Brazilian population. But only by constantly reproducing instantaneous and direct identification, stoking Twitter controversy, resurrecting the country's institutional decay, and tilling the soils of moral panic, can Bolsonaro continue to titillate his hard-core followers. ${ }^{86}$ The sensation of participating in a Bolsonarista WhatsApp group is one of popular power, however illusory in reality, of the capacity to support, sculpt, and scold the politics of one's leader, while rallying to his defence against enemies, internal and external. The sensation of immediacy, of 'participatory ecstasy', is something many Bolsonaro supporters never experienced via the traditional political system. ${ }^{87}$

\footnotetext{
$83 \quad$ Fogel 2018.

$84 B B C$ News 2019. There is some controversy over how many of his apparent Twitter followers are actually bots.

85 Toscano 2017.

86 Nobre 2019 .

87 Ibid.
} 
There may be an underlying rationale to the form of rule assumed by this inarticulate, undexterous clown, this interloper president, maligned by the mainstream media: 'the factor that more often than not the fascist leader appears as a "ham actor" and "asocial psychopath" is a clue', Toscano reminds us, 'to the fact that rather than sovereign sublimity, he has to convey some of the sense of inferiority of the follower, he has to be a "great little man".'88 Bolsonaro performs simultaneously as charismatic leader and man of 'the people', someone sharing 'their language, tastes, and culture.' 89 'Bolsonaro, the nobody - a citizen of failure - won the elections, embodying the worst features of Brazilian politics, and of Brazilian society, within himself' - coursing through his blood, the ideological cocktail of anti-corruption, anti-crime, the hard state, and evangelical moralism. ${ }^{90}$

\section{$5 \quad$ State Factions}

It is time now to interrogate the complex entanglements of cultural authoritarians, militarists, and neoliberal technocrats at the heart of the government in question. There are tensions and contradictions working between them, although there are also instances of overlap in specific personnel who bridge the divides, as well as moments of coincidence across currents in ideological and political purpose. Without forgetting the malleability of these lines of separation, then, let us review each faction in turn.

\section{$5 \cdot 1$ \\ Cultural Authoritarians}

Bolsonaro himself is the peak representative of the first group. The adhesive glues of this tendency involve a support base in evangelical Pentecostalism and right-wing Catholicism, an admiration for Donald Trump, antipathy toward China, aggressive hostility to Venezuela, a Zionist commitment to Israel, and such esoteric notions as Nazism being a leftist movement. ${ }^{91}$ Joining the president in the innermost ring are three sons from his first marriage - Flávio, 38, a former lawyer, member of the legislative assembly of the state of Rio de Janeiro for the Progressive Party (PP) from 2003 to 2016, and the PSL from 2016 to 2018 , and since 2019 a senator for PSL at the federal level; Carlos, 37, a city

\footnotetext{
88 Toscano 2017.

89 Garcia 2019.

90 Political Economy Research Centre (PERC) 2019.

91 Schipani and Harris 2019.
} 
councillor in Rio de Janeiro for the Social Christian Party (PSC) since 2001; and Eduardo, 35, a former police officer and lawyer, and member of the chamber of deputies from São Paulo from 2014 to 2018 with the PSC, and from 2019 onwards with the PSL. ${ }^{92}$

Eduardo, the youngest of the brothers, is perhaps the most extreme sibling. He is the Latin American representative of Steve Bannon's far-right international organisation, the Movement. Eduardo, long an admirer of Bannon, took it upon himself to introduce Bannon to Carvalho during a visit to the United States. The two men hit it off. For Bannon, Carvalho incarnates a new source of vitality for what he sees as increasingly sterile traditional frames of reference within American conservatism. ${ }^{93}$ In a 2018 video, Eduardo can be seen and heard contending that the recent spate of US school shootings is the consequence of schools being 'gun-free' zones. Legislators protecting that reality are ultimately culpable for the massacres. ${ }^{94} \mathrm{He}$ won a record 1.8 million votes in last year's congressional elections, securing his membership in the Chamber of Deputies. ${ }^{95}$

Carlos, the middle son, is known as the 'pit bull', both for outspoken loyalty to his father, as well as the role he played as coordinator of Bolsonaro senior's social-media campaign during the electoral race. Carlos subsequently became the unofficial spokesperson of the presidency of the new regime, and the most vehement antagonist of Hamilton Mourão, vice president and chief representative of the militarist faction. ${ }^{96}$

If Carlos has attracted controversy in the press for his role as pit bull, Flávio has also drawn unwanted attention. He is under investigation for corruption concerning alleged payments to a former adviser and other suspect financial transactions, becoming a vulnerable flank for the Bolsonaro administration, given that a key part of its raison dêtre has been a concerted war on corruption, which it treats as essentially a phenomenon exclusive to the PT. ${ }^{97}$ Flávio also employed the mother and wife of a former police officer in Rio who is the alleged leader of a violent urban militia. ${ }^{98}$ Flávio, like his father and brothers, is a fierce advocate of gun ownership as an individualised means of responding

\footnotetext{
92 Bolsonaro has another son, Renan, from his second marriage, and a young daughter Laura - from his present marriage. He has famously said of his daughter that she reflected a moment of 'weakness' on his part.

93 Dieguez 2019.

94 Leahy and Schipani 2018.

95 Ibid.

96 Harris and Schipani 2019c.

$97 \quad$ Fogel 2o19b.

98 Schipani 2019.
} 
to violent crime. In 2017, he shot a pistol through his own car windshield in the middle of a Rio traffic jam in an attempt to gun down a suspected thief. ${ }^{99}$

With this family dynasty at its core, the faction of extreme ideologues also encompasses the ministries of education and foreign affairs. ${ }^{100}$ Bolsonaro's first education minister was Ricardo Vélez Rodríguez, an obscure, ultraconservative academic, whose main credential for the position was seemingly his tightknit association with Carvalho. Under his leadership, the ministry became a battlefield between cultural authoritarians and militarists. Vélez Rodríguez's main efforts in the post were symbolic attempts to rewrite the portrayal of the military dictatorship in the public-education curriculum and to introduce the national anthem into schools - the singing of which was to be followed by the children chanting the Bolsonaro rally cry, 'Brazil Above Everything, God Above All!'101

Overstepping his authority one too many times, Vélez Rodríguez was forced from his position in early April 2019, to be replaced by an ostensibly moderate technocrat, economist Abraham Weintraub. It is true that Weintraub has been more amenable to repairing bonds with the militarist faction, and yet his commitment to bringing the war on 'cultural Marxism' into the public-education system rivals that of Carvalho. Like Vélez Rodríguez, Weintraub was unaccomplished as a scholar. A fierce adherent of austerity in the education sector, he is the author of the proposed reforms that catalysed the mass mobilisations of May 15 and 30, 2019. ${ }^{102}$ Prior to taking up a position at the Universidade Federal de São Paulo, Weintraub had been director and chief economist at Votorantim Bank. Weintraub is a close friend of cultural extremist Eduardo Bolsonaro, but he is also a neoliberal dogmatist, suggesting elective affinities with the technocratic faction. His appointment is understood by many pundits to represent an attempt to repair some of the ill will between the main regime factions. ${ }^{103}$

In the realm of foreign affairs, Filipe Martins, a 32 -year-old advisor to the president, adherent of Carvalho, and former international-affairs secretary of the PSL, has played an important role in setting the tone of this administration. ${ }^{104} \mathrm{He}$ is closely aligned with Ernesto Araújo, Minister of Foreign Affairs, and, with the customary ardour of youth, one of the more unrelenting reactionaries in the present government.

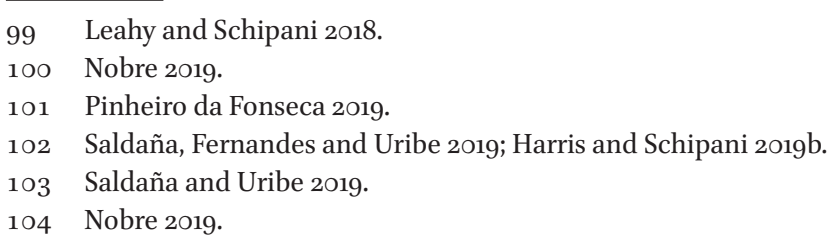


Araújo himself apparently owes his ministerial position to a direct endorsement from Carvalho. The West Virginia resident became aware of Araújo when the latter published a bewitched treatment of the US president and the new wave of far-right governments internationally in an article called 'Trump and the West', appearing in a 2018 issue of the Cadernos de Política Exterior, the quarterly journal of the Brazilian Institute for Investigation of International Affairs, IPR I. ${ }^{105}$ Araújo recognises his debt to Carvalho and remains one of the guru's most loyal disciples within government. This explains in part Araújo's tense relations with career diplomats and civil servants in the ministry under his command, as well as conflicts with the militarist faction. ${ }^{106}$

Under Araújo's command of the foreign-affairs portfolio, Brazil has played a leading role in the dismantling of the South American Community of Nations (Unasur), which had sought some degree of regional autonomy for South America from US hegemony in recent years, and its replacement by the Forum for the Progress of South America (Prosur), which thus far coheres around the right-wing governments of Brazil, Argentina, Colombia, Chile, Paraguay, Peru and Ecuador. ${ }^{107}$ Araújo is a hawk with regard to neighbouring Venezuela, and so it is no surprise that Brazil was one of the first countries to recognise the self-anointment as interim president of Brazil's northern neighbour by conservative oppositionist Juan Guaidó. ${ }^{108}$ The foreign-affairs minister coordinated a meeting between Bolsonaro and the Venezuelan opposition in Brasília on January 17, 2019, just days before Guaidó's declaration. According to Araújo at the time, the Venezuelan government of Nicolás Maduro has only been capable of reproducing itself through 'generalised corruption, narco-trafficking, people trafficking, money laundering, and terrorism.'109

Araújo is an open admirer of the far-right nationalist governments of Italy, Hungary and Poland. He was personally behind the extradition of Cesare Battisti, a long-time political exile and novelist in Brazil who was wanted by the Italian state for his involvement in the 197os far-left group, Armed Proletarians for Communism (PAC). ${ }^{110}$ Araújo's brand of nationalism involves

\footnotetext{
105 Dieguez 2019.

106 Della Coletta 2019.

107 Caccia Bava 2019. Lenin Moreno, Ecuador's president, was elected in 2017 on a platform of continuity with Rafael Correa's administration. However, he made a sharp turn to the right almost immediately after assuming office.

108 Uribe and Fernandes 2019.

109 Dieguez 2019.

110 Caccia Bava 2019. Shamefully, the Bolivian government of Evo Morales participated in the extradition after Battisti fled Brazil for Bolivia. Morales was also one of the only presidents not affiliated with the conservative right in the region to have attended Bolsonaro's inauguration.
} 
the notion that Brazil can play a bigger and bolder role on the world stage, but only if it subordinates itself in a tight alliance with the United States, under Trump's leadership. ${ }^{111}$

Aligning with Israel in the Middle East is one way to strengthen allegiances with the United States. 'When Americans see that we have positions close to theirs in discussions on the Middle East', Araújo stresses, 'it makes it easier to reach out to them to discuss issues of wheat or ethanol.' Because of Brazil's renewed ties to the United States, if a country is inclined to take an attitude hostile to Brazil's interests, 'it is going to think twice, because it will see that Brazil has this alliance.'112 Araújo was warmly received by Trump in an April 2019 trip to Washington, and returned to Brazil with a series of announcements concerning gains made on the trip - Washington signalled support for Brazil's aim to join the Organization for Economic Cooperation and Development (OECD), and affirmed its commitment to elevate the South American country to the status of a preferential ally of the North Atlantic Treaty Organization (NATO). ${ }^{113}$

China, meanwhile, represents a long-term existential threat in the worldview of the minister of foreign affairs, both in terms of commercial expansion throughout much of the world, and of its geostrategic positioning vis-à-vis the United States. For Araújo, it is clear that China will become an ever-bigger problem for the 'West' over time. As the line being drawn between the United States and China becomes sharper, bold alignment with the former must be the option pursued by Brazil. Still, Araújo has been unable simply to ignore the dependent ties of Brazilian exporters to the Chinese market. When he is pushed by journalists to clarify if his most hawkish statements vis-à-vis China mean that Brazil will reduce its commercial linkages with the Asian power, Araújo always returns to pragmatism, acknowledging that China will continue to be a major trading partner of Brazil. ${ }^{114}$

A final figure of note in the Bolsonaro regime's cultural authoritarian contingent is Damares Alves, a ferociously conservative evangelical pastor who was given the reigns of the ministry of family, women, and human rights. ${ }^{115}$ In addition to playing a leading part in the government's ceaseless propaganda war on 'gender ideology', Alves's ministerial remit has been extended to include Brazil's Indigenous Affairs Agency (FUNAI). In this domain, Alves draws on her experience evangelising in Indigenous areas of the country to execute

\footnotetext{
111 Dieguez 2019.

112 Ibid.

113 Della Coletta 2019.

114 Dieguez 2019.

115 This new ministry replaced the old ministry of human rights.
} 
Bolsonaro's horrifying vision of the Amazon, environment, and Indigenous territories. A key facet of the president's perspective in this area is the ostensible alignment of Indigenous interests with those of corporate mining and agricultural giants. ${ }^{116}$

\subsection{Militarists}

In contrast to the pomp and spectacle of the cultural authoritarians, the militarists, whose most visible representative is vice president Hamilton Mourão, project a comparatively quiet resolve. If the Brazilian populace has generally turned against most state institutions, polling suggests that popular confidence in the armed forces remains high, indeed the highest of any state institution. ${ }^{117}$ Augusto Heleno Ribeiro, a former general who oversees security policy in the cabinet, says the military's reputation for moderation is well-deserved: 'Our style is to be conciliatory, not incendiary.... That's because we know full well the perils of extremism.'118 Should Bolsonaro's ineptitude in serving the interests of capital persist too much longer, the direct usurpation of power by Mourão is one plausible exit. "The bickering and resultant policy paralysis' of Bolsonaro's first period in office 'has raised questions about Mr. Bolsonaro's political skills and future', the Financial Times reports. 'In a country with a history of vice-presidents rising to the highest office, analysts wonder if General Mourão is not already a president-in-waiting.'119

Lacking an institutional machinery comparable to the Republican Party in the United States, which remains capable of disciplining Trump in myriad ways, the Brazilian armed forces, and the army in particular, has provided a necessary infrastructural bedrock for the Bolsonaro administration. 'Depending on the form of state and regime and on the phase of reproduction of capitalism,' Nicos Poulantzas observes, 'a number of apparatuses can slide from one sphere to the other [repression-ideology] and assume new functions either as additions to, or in exchange for, old ones. To take a typical example, the army becomes in certain forms of military dictatorship an ideological-organizational apparatus functioning above all as a party of the bourgeoisie.'120

Reflecting Brazil's well-established sub-imperial role in the region - as much under the PT as under the rule of traditional bourgeois parties - many of the

\footnotetext{
116 Phillips 2018b; J.L. Anderson 2019.

117 Victor 2019.

118 Quoted in Londoño and Casado 2019.

119 Schipani and Harris 2019.

120 Poulantzas 1978, p. 33 .
} 
key military figures staffing the state since January 2019 have been drawn from personnel whose formative experience was Brazil's occupation of Haiti, part of a wider mission of the United Nations. ${ }^{121}$ Labelled 'the Haitian Generals', this group has overseen the insertion of 103 military figures into the various strata of state apparatuses under Bolsonaro - from the vice presidency, to ministries, to federal banks, to municipalities, and to strategic state enterprises, such as Petrobras. ${ }^{122}$

According to a poll conducted in early April 2019, 6o per cent of Brazilians consider the participation of military representatives in the Bolsonaro government to be positive. Apart from the president (himself an ex-army captain) and the vice president, representatives of the armed forces occupy six of 22 ministries, including Fernando Azevedo as defence minister. Two other ministers have had military training. Members of the army, air force, and marines occupy dozens of positions of note in the current government. Exemplary cases are the head of the National Department of Infrastructure and Transportation (DNIT) and key positions within FUNAI. If the president's most prominent, informal Twitter spokesperson is Carlos the pit bull, the formal position of chief spokesperson is occupied by General Rêgo Barros. ${ }^{123}$

While the social-media warriors of Bolsonaro's inner circle play a critical role in securing the otherwise-exhaustible zeal of the grassroots, 'the military ensures that this reality show does not undermine the functioning of the machinery of the state, and, therefore, of the government.'124 Mourão presents himself as the face of institutionality in a government which loathes institutions, of good sense in a government which lacks it entirely, of equilibrium, in a government which sows uncertainty as a matter of course. In so doing, he has earned the special and concentrated opprobrium of Bolsonaro's sons and their sage in West Virginia. However, to date, the pageantry of these melees has not translated into genuinely irresolvable conflict between the militarists and the cultural authoritarians.

On a trip to Washington in April 2019, Mourão held a series of public events as well as closed-door meetings with US senators and the American vice president Mike Pence. US business representatives who met with him praised the general's calm and firm temperament. Citigroup's CEo for Latin America, Jane Fraser, for example, suggested that Mourão's tranquil and firm comportment is a necessary ingredient for investor confidence in the Brazilian government.

\footnotetext{
121 Zibechi 2012.

122 Nobre 2019.

123 Folha de São Paulo 2o19b.

124 Nobre 2019.
} 
In his speeches to US investors, Mourão, in accordance with neoliberal technocrats, consistently defended the necessity of implementing radical pensionand tax reforms, as well as wide-scale privatisations. ${ }^{125}$

As late as 2018, it would have been difficult to imagine Mourão's selfreinvention as a voice of reason and moderation. Until recently, he was generally seen as one of the most aggressive proponents of a return to military dictatorship after decades of democratic rule. The five-star general was pressured to resign shortly before he was fingered as Bolsonaro's vice-presidential candidate. He managed to miscalculate acceptable limits to open adherence to authoritarian rule during the late period of Dilma's rule - 'he had openly attacked Dilma's government; declared that if the judiciary failed to restore order in Brazil, the military should intervene to do so; and floated the idea of an "auto-coup" by an acting president, should that be necessary.'126 Mourão, who is of Indigenous descent himself, has berated the 'laziness' of Brazil's Indigenous population, has lamented the 'trickery' of the country's descendants of African slaves, and has explained that the only reason his grandson is handsome is a consequence of the 'whitening' of the population through European migration. ${ }^{127}$

It is undoubtedly true that military-civilian relations changed with the return of liberal-democratic rule in 1985. And yet, certain dark legacies of the way the democratic transition unfolded remain at play to this day. Unlike neighbouring Argentina, where the military was vanquished by the Malvinas/Falklands War and a resurgent popular movement for democracy, the Brazilian dictatorship ultimately collapsed as a result of internal disputes within the armed forces. There was no comparable popular insurgent pressure from below. Coming 'from above' in this way, the nature of the transition has to some extent insulated the Brazilian armed forces from democratic accountability.128 One reflection of this is the total autonomy enjoyed by the military educational system, of which Bolsonaro is a product. ${ }^{129}$ The core history texts taught in these schools present the military coup of 1964 as a democratic revolution, carried out by moderate groups respectful of law and order. They omit entirely the assassinations, repression of human rights, and torture committed during the dictatorship. ${ }^{130}$

\footnotetext{
125 Dias and Campos Mello 2019.

126 P. Anderson 2019.

127 Schipani and Harris 2019.

128 Fuccille 2019.

129 Penido 2019.

130 Victor 2019.
} 
In recent years, the reach of the armed forces into civilian affairs has been extended. Beginning in the first administration of Dilma (2011-14), the armed forces were assigned a major role in domestic-policing tasks in the name of restoring public security. Under Temer (2016-18), military influence grew further, with the reinstatement of ministerial status for the Cabinet of Institutional Security (GSI). The armed forces were also called upon to militarily intervene in the favelas of Rio de Janeiro between February and December 2018. ${ }^{131}$ In the lead up to the October 2018 elections, various representatives of the armed forces let it be known, off record, that they would not accept another PT government. 132

Although I have placed Bolsonaro firmly within the ranks of the cultural authoritarians, he nonetheless shares many of the commitments of the militarists. For the first time since the end of the dictatorship, Brazil has a president who denies all evidence of the crimes committed by the military during the dictatorship, and who holds up one of the officials most associated with torture, Coronel Alberto Brilhante Ustra, as an exemplar for others. Bolsonaro is committed to a full alteration of the historical memory of the period, beginning with the idea that 1964 was not a coup, but rather a necessary initiative taken by the military in defence of democratic values. ${ }^{133}$ Bolsonaro announced his intention to memorialise the fifty-fifth anniversary of the 1964 coup on March 25 early in his term, but was forced to back down in the face of public discontent. ${ }^{134}$ According to Datafolha, the majority of the population (57 per cent) continues to think the day inaugurating 21 years of dictatorship should be condemned. 36 per cent of Brazilians nonetheless support the president's efforts to rewrite history.135

\subsection{Neoliberal Technocrats}

Next to the cultural authoritarians and militarists, a third current of neoliberal technocrats has been central both to Bolsonaro's rise to office, as well to the design of the government's political-economic and anti-corruption programmes. The latter task has fallen to Sergio Moro, the ex-federal judge responsible for heading up the Lava Jato 'carwash' investigations into corruption, which ultimately underpinned the impeachment of Dilma and the imprisonment of

\footnotetext{
131 Fuccille 2019.

132 Ibid.

133 Victor 2019.

134 Uribe and Fernandes 2019.

135 Marques 2019.
} 
Lula. ${ }^{136}$ After the first round of the 2018 elections, Bolsonaro brought Moro under his wing, promising him the ministry of justice and public security should he become president. Moro quickly became the most popular minister in the cabinet, recognised by $93 \%$ of poll respondents, and with an unmatched approval rating of $74 \%{ }^{137}$ Moro's fame is the product of his leading role in a carefully manufactured politicisation of corruption investigations dating back to 2006. 'Successive operations - raids, round-ups, hand-cuffs, confessions were given maximum publicity', Anderson points out, 'with tip-offs to the press and television, each carefully assigned a number (to date there have been 57 , resulting in more than a thousand years of jail sentences) and typically a name chosen for operative effect from the cinematic, classical, or biblical imaginary.'138

While Moro's public persona is one of dispassionate, judicious restraint, he happily assumed responsibility for one of the most reactionary pieces of legislation under Bolsonaro's reign thus far. A package of anti-crime bills was passed into law under Moro's watch with the ostensible aim of cracking down on endemic levels of violence. According to the new legislation, judges now possess the freedom to grant immunity to police officers who have killed civilians, provided the police officers can show that during the incidents in question they were subject to 'violent emotion, excessive fear, or surprise'. This is an extraordinary licence to kill in a country where the number of annual police executions was already legendary. ${ }^{139}$ According to the Brazilian Annual Public Security Report, in 2017, Brazilian police forces killed 14 people per day, 5,144 over the course of the year - a 20 per cent increase relative to 2016. In 2017, 367 police officers were killed, an average of one per day. The uptick in police repression had no demonstrable effect on its purported aim, the reduction of homicides, of which there were 63,880 that year, 3 per cent more than in $2016 .{ }^{140}$ In 2018, with Rio de Janeiro's favelas subject to military intervention at the behest of Temer, there were 1,532 officially registered killings by police. In 2019, the numbers were impressive: 170 dead in January alone. After the apparent execution of 15 young men by police after they had been detained, Wilson Witze, the governor of Rio, immediately declared the police actions to have been legitimate. ${ }^{141}$

The anti-crime package overseen by Moro links back to an earlier presidential decree which freed up access to gun possession. In an intensely volatile

\footnotetext{
136 Singer 2018; Boito 2018.

137 Folha de São Paulo 2019c.

138 P. Anderson 2019.

139 Freixo 2019.

140 Ibid.

141 Vianna 2019.
} 
combination, people have been granted even further access to guns while juridical freedom has been expanded such that vigilante assassinations can be framed as legitimate defence. ${ }^{142}$ Despite everyday insecurity clearly having played a role in the election of Bolsonaro, recent polls indicate most Brazilians are unconvinced that the anti-crime package will actually improve their safety. For the majority of Brazilians, the possession of guns should be prohibited $(64 \%)$, and society will not be more secure if people are better armed to protect themselves $(72 \%)$. Police should not be free to shoot suspects because they might kill innocent bystanders ( $81 \%)$, and in instances where the police do kill, they should be investigated $(79 \%)$. Pertinently, those police officers who shot someone because they were in a heightened state of nervousness should be punished $(82 \%) .{ }^{143}$ Nonetheless, these polling figures have not translated into disapproval of Moro himself.

In a certain sense, Moro embodies the ideological conjoining of anticorruption and state violence at the heart of Bolsonarismo. But he does so in a tempered voice, and with the measured, juridical rationality of the bourgeois state - a liberal cover for state murder. Moro is able to do so within Bolsonaro's more general framework of rule. The president 'consolidates in himself the programme of the far-right, a programme that focuses on corruption to give it legitimacy, and which focuses on a strong state, using the argument of violence', Saad-Filho explains.

But the idea is that if communities are insecure, more police and more violence will resolve this problem. A discourse that was connected to neoliberalism, again, because the state is intrinsically corrupt, so the way to resolve the problem of the state is to take it off the backs of the citizens through a neoliberal programme. But you don't talk about the programme itself, you talk about liberating people from the yoke of a state which is intrinsically corrupt. ${ }^{144}$

Moro does the work of operationalising this idea of a lean, hard, and clean state.

An agile operator, Moro is as comfortable in the sphere of social media, where he has plenty of followers, as he is in the more sedate corridors of power. He forges alliances with militarists in order to ensure the proper functioning of his ministry. At the same time, he obeys the diktats of Bolsonaro and

\footnotetext{
142 Freixo 2019.

143 Mena 2019.

144 Political Economy Research Centre (PERC) 2019.
} 
his familial dynasty whenever necessary, and he avoids contradicting them publicly. ${ }^{145}$ Should some kind of coup ever play out involving the removal of Bolsonaro and Mourão's temporary seizure of the presidency, Moro would have been one logical candidate in the likely hasty search to follow, wherein an ex post facto civilian face would need to be found to legitimise the new regime.

But Moro's luck ran dry in June 2019. An anonymous source provided investigative journalists at The Intercept with a treasure trove of 'private chats, audio recordings, videos, photos, court proceedings, and other documentation' which reveal 'highly controversial, politicized, and legally dubious internal discussions and secret actions by the Operation Car Wash anti-corruption task force of prosecutors, led by the chief prosecutor Deltan Dallagnol, along with then-judge Sergio Moro.'146 The Intercept unleashed its first flurry of reports in early June, with many more apparently in the pipeline based on an archive of materials now in their possession (and also safely secured outside Brazil, should the government intervene).

The investigative reports published thus far indicate unambiguously that the Car Wash prosecutors were fundamentally motivated by the desire to prevent a return of the PT to power, and that Moro secretly collaborated with them on various fronts to ensure this outcome, even while presenting himself as a neutral arbiter of justice. This was long suspected by PT supporters and critics of the Bolsonaro government, but hard proof had been lacking until now. ${ }^{147}$ 'Telegram messages between Sergio Moro and Deltan Dallagnol reveal that Moro repeatedly stepped far outside the permissible bounds of his position as a judge while working on Car Wash cases', one of the published reports indicates. 'Over the course of more than two years, Moro suggested to the prosecutor that his team change the sequence of who they would investigate; insisted on less downtime between raids; gave strategic advice and informal tips; provided the prosecutors with advance knowledge of his decisions; offered constructive criticism of prosecutorial findings; and even scolded Dallagnol as if the prosecutor worked for the judge.'148

There is also clear documentation in the journalists' archives that Dallagnol had serious doubts about the basic constitutive evidence in the case against Lula, in particular whether a beachfront triplex apartment that Lula was accused of receiving as payback for doling out multimillion-dollar contracts with Petrobras was actually Lula's, and whether it in fact had anything to do

\footnotetext{
145 Nobre 2019.

146 Greenwald, Demori and Reed 2019.

147 Ibid.

148 Fishman, Moro Martins, Demori, de Santi and Greenwald 2019.
} 
with Petrobras (the latter being especially important jurisdictionally, because without the involvement of Petrobras the case could not have been tried by Moro in Curitiba). ${ }^{149}$

When the PT was in office, the judiciary morphed into what Poulantzas would call a 'refuge-centre' of the bourgeoisie within the state:

Even when a Left government really controls state branches and apparatuses, it does not necessarily control the one or ones which play the dominant role in the state and which therefore constitute the central pivot of real power. The centralized unity of the state does not rest on a pyramid whose summit need only be occupied for effective control to be ensured. Moreover, even when a Left government manages to gain control of the hitherto dominant apparatus, the state institutional structure enables the bourgeoisie to transpose the role of dominance from one apparatus to another. In other words, the organization of the bourgeois state allows it to function by successive dislocation and displacement through which the bourgeoisie's power may be removed from one apparatus to another: the state is not a monolithic bloc, but a strategic field.... Still, the very process of permutation tends to reorganize the centralized unity of the state around the newly dominant apparatus - an apparatus which thereby becomes the supreme refuge-centre of bourgeois power in the state, remaining in operation as such throughout the period of Left government. ${ }^{150}$

In Brazil under the PT, the dislocation and displacement of bourgeois power of which Poulantzas speaks found renewed concentration in the judicial apparatus, working in close concert with the prosecution and private media.

The significance of The Intercept's findings is already clear as day, even if there are still many more stories to be published. Moro convicted Lula after clandestinely and illegally collaborating with the prosecutorial team at a time when Lula was leading in the polls of the 2018 presidential race by a wide margin. Only after Lula's conviction and the PT's switch to Haddad as candidate did Bolsonaro's numbers begin to rise. ${ }^{151}$ Without Moro's actions it is very far from obvious that Bolsonaro would ever have been elected. 'That the same

\footnotetext{
149 Ibid.

15 O Poulantzas 1978, p. 138.

151 Moro initially sentenced Lula to nine years and six months in prison. As The Intercept journalists report, 'the ruling was quickly upheld unanimously by an appeals court and the sentence was extended to 12 years and one month. In an interview, the president of the appeals court characterized Moro's decision as "just and impartial" before later admitting that he had not yet obtained access to the underlying evidence in the case. One of
} 
judge who found Lula guilty was then rewarded by Lula's victorious opponent made even longtime supporters of the Car Wash corruption probe uncomfortable', The Intercept journalists go on to point out, 'due to the obvious perception (real or not) of a quid pro quo, and by the transformation of Moro, who long insisted he was apolitical, into a political official working for the most far-right president ever elected in the history of Brazil's democracy. Those concerns heightened when Bolsonaro recently admitted that he had also promised to appoint Moro to a lifelong seat on the Supreme Court as soon as there was a vacancy.'152

However important Moro has been to Bolsonaro's calculus of power, it was economist and financier Paulo Guedes who eased into place the unlikely marriage between the nationalist ex-captain and capital. Bolsonaro had exhibited no earlier sympathies for neoliberal economics, favouring state subsidies and protections for his military voting base when, as a congressperson, he occasionally assumed substantive positions. 'In the sequence of Bolsonaro's rise', long-time Brazil observer Peter Evans notes, 'the figure of Paulo Guedes rivals that of Judge Sérgio Moro. If Moro and his judicial allies did the negative work of removing Lula, Guedes did the positive work of building capital's confidence that Bolsonaro's economic agenda would serve their interests.'153

Guedes was a co-founder of the largest private investment bank in Brazil, в G G Pactual, and has amassed considerable wealth. An authentic Chicago Boy, having received his doctoral training in the department of economics at the University of Chicago, Guedes's clearest expression of unrestrained commitment to Milton Friedman's monetarism was perhaps his move to Pinochet's Chile in the 198 os to take up an academic post. It was in part the promise of a comparable union between liberal economics and authoritarian rule that drew him into Bolsonaro's quest for state control. 'People asked me', he explained to the Financial Times, how can a liberal join conservatives? They will only bring disorder. But disorder is already here.... The president will bring "order," the liberals "progress"', Guedes said, with reference to Brazil's national slogan, 'order and progress.'.154

A purer technocrat than Moro, Guedes does not understand the world of social media. Similarly, his attempts to navigate the labyrinthine politics of coalition-building in congress have not borne fruit. When he recognised

the three judges on the panel was an old friend and classmate of Moro's.' (Fishman, Moro Martins, Demori, de Santi and Greenwald 2019.)

$15^{2}$ Greenwald and Pougy 2019.

153 Evans 2018.

154 Schipani and Rathbone 2019. 
Bolsonaro was not going to assist in the passage of his prized pension-reform agenda, Guedes attempted to establish direct lines of communication with Rodrigo Maia, president of the lower house. However, Maia insisted on Bolsonaro's direct involvement, inviting upon himself a barrage of insults from Bolsonaro loyalists, and the following statement towards the end of March 2019, directly from the president: 'I do not really want to carry out the pension reform.' ${ }^{155}$ At one point, in apparent exasperation at his inability to move pension reform forward due to tensions between the president and congress, Guedes threatened to walk off the job and return to the lucrative world of investment banking. ${ }^{156} \mathrm{He}$ never followed through on the threat, however, and remained committed to constructing the necessary alliances to pass his pension-reform agenda. ${ }^{157}$

Accompanying Guedes in Bolsonaro's neoliberal dream-team until June 2019, Joaquim Levy assumed the role of president of the massive Brazilian Development Bank (BNDES). Here we see some of the continuities with the period of PT rule. Levy held several positions in the International Monetary Fund, and was President of a division of Bradesco, Brazil's second largest private bank, before taking the reins as minister of finance at the beginning of Dilma's second term in office in 2014 - a misjudgement on Dilma's part, based on a wager that the PT might still project 'credibility' to finance capital through an orthodox finance minister. Following his brief stint in Dilma's cabinet, Levy worked as the World Bank's Chief Financial Officer, until he accepted the presidency of BNDES. ${ }^{158}$ On 16 June 2019 Levy resigned from his position after being criticised by Bolsonaro. He was replaced by Gustavo Montezano, a long-serving drinking companion of Eduardo Bolsonaro. ${ }^{159}$

Meanwhile, in the ministry of agriculture, Tereza Cristina da Costa, a longtime congressperson for DEM, from the state of Mato Grosso do Sul, is a direct representative of agribusiness interests. ${ }^{160}$ Onyx Lorenzoni, also linked to the agricultural lobby groups, and likewise a member of DEM, is Bolsonaro's chief of staff, whose unenviable job it is to coordinate the disparate allied parties of the regime in congress, and mediate the conflicting agendas of the three principal factions within the governing apparatus. ${ }^{161}$

\footnotetext{
155 Nobre 2019.

156 Harris, Bryan and Schipani 2019a.

157 Folha de São Paulo 2019f.

158 Schipani 2018.

159 O Globo 2019.

160 Schipani 2018.

161 Nobre 2019.
} 
Thus far, as we have seen, the three factions have been unable to carry out even the minimum elements of Bolsonaro's policy agenda. If capital is not to abandon ship, performance on the economic front in particular will have to change. Again, Poulantzas's description of weakening government policy capacity in states characterised by hollowed-out and fragmented party systems is apposite:

Given the very nature of administrative procedures, regulation of conflicts and compromises within the bloc takes place in a more or less jerky and concealed manner - through abrupt movements, direct clashes between administrative sub-apparatuses and sub-bureaucracies, and through short-term bargains referring to individual cases. This contributes to the characteristic incoherence of present-day government policy, marked as it is by lack of a long-term, articulated strategy for the power bloc and by the absence of a global politico-ideological or 'social' project. Such flying blind is a most hazardous course for the functioning of class hegemony.... Disputes among various clans, factions and fiefs of the administration are extrapolated into political divisions, setting up shock-waves in the state that call into question its role as organizer of hegemony. ${ }^{162}$

\section{$6 \quad$ Rudderless Economics}

Bolsonaro has been resolutely incapable of lifting the economy out of the impasse it entered as a result of the delayed reverberation of the global crisis, which finally reached the shores of Brazil in $2013 .{ }^{163}$ Favourable external economic circumstances under Workers' Party rule for both of Lula's administrations, and part of Dilma's first term, had allowed for 'the virtuous dynamics of the labour market, including rising wages and employment, the formalisation of labour, higher transfers and improved social security provision while, at the same time, allowing the government to deliver low inflation and the fiscal surpluses demanded by the neoliberal elite.' 164

All of this ended in 2013 as GDP growth entered freefall: $3.0 \%$ in 2013, $0.5 \%$ in $2014,-3.6 \%$ in $2015,-3.3 \%$ in 2017 , and $1.3 \%$ in $2018 .{ }^{165}$ Defying the United Nations Economic Commission for Latin America and the Caribbean's (ECLAC)

\footnotetext{
162 Poulantzas 1978, p. 246.

163 Webber 2017, Chapter 2.

164 Saad-Filho and Morais 2018, pp. 8o-1.

165 CEPAL 2019, p. 101.
} 
projections of a Brazilian recovery in 2019, the country's economy contracted in the first quarter and finished the year overall with $1.0 \%$ growth. According to official statistics, 13 million people are unemployed, millions more underemployed, and 55 million people live below the obscenely low poverty line of five dollars and fifty cents a day, an additional 3 million since 2016..$^{166}$

Of course, these aggregate figures mask the gendered, racialised, and generational characteristics of the labour market. By one estimate, of the nearly 3 o million underemployed in Brazil, black women constitute $36 \%$. Of the total unemployed in 2018, 54\% were young people between the ages of 14 and $29 .{ }^{167}$ The demographics for occupations of low productivity and low salaries (between one and two minimum salaries) are striking. $82 \%$ of economically active black women are employed in this stratum, $63.4 \%$ of white women, $72.6 \%$ of black men, and 50.5\% of white men. Informal labour - understood as jobs without contract, domestic work, own-account work, and employment within the family - constitutes $50.4 \%$ of all jobs, an $8 \%$ climb from 2014 figures. ${ }^{168}$

'What happens with Bolsonaro will tell us what is going to happen with the new right in Latin America', long-time analyst of regional affairs Claudio Katz told me in an interview in Buenos Aires in early May 2019. 'And the problem is that the government of Bolsonaro, in the three months or so that he has been in power, is a joke, a laugh, a record of nonsense.' For Katz, the new conservative wave in Latin America, of which Bolsonaro represents the leading edge, lacks direction, vision and coherence. 'The bases for the conservative restoration are fragile', he explains,

because the classical neoliberal economic project of the 199os and 2000 s in Latin America now runs up against a changed international scenario. As a result, the neoliberals are bewildered, unsettled, do not know what to do. And that seriously erodes the political project of conservative restoration.... We are in the midst of a conservative restoration characterised by zombie neoliberalism, and therefore the prospects are wide open. ${ }^{169}$

Compounding the domestic economic incompetency of the government, in its latest forecast, published in early April 2019, the International Monetary Fund downgraded its expected rate of growth for the world economy (global

\footnotetext{
166 Levinas 2019.

167 Oliveira Teixeira 2019.

168 Ibid.

169 Personal Interview, Claudio Katz, Buenos Aires, 5 May 2019.
} 
GDP) to $3.3 \%$ for $2019 .{ }^{170}$ An intensifying trade war between Donald Trump and Xi Jinping is helping to improve the odds that global growth might worsen even further, to $2.5 \%$, the 'stall speed' beneath which a recession is signalled. ${ }^{171}$ There will be no outside saviours for the Brazilian economy, which has come to depend increasingly on primary exports of soy, oil, beef, and mining minerals. By April 2019, Brazilian industry accounted for the smallest part of GDP in 70 years. ${ }^{172}$ With good reason, the percentage of citizens who expect the Brazilian economic situation to improve fell from 65\% in December 2018 to $50 \%$ in April 2019, according to Datafolha. ${ }^{173}$

Initially, international markets and the leading financial press welcomed Bolsonaro's presidency as a continuation and deepening of the aggressive neoliberal restructuring introduced under the short-lived, much-hated, and unelected presidency of Michel Temer - Dilma Rousseff's former vice-President, and an inveterate turncoat and swindler. ${ }^{174}$ During his brief tenure, Temer was able to enact ' what may be the most substantial regressive change in labour legislation in 75 years, forcing Brazilian workers back into precarious work.' ${ }^{175}$ In 2018, on the back of Temer's assault on popular livelihoods, reported profits of companies listed on São Paulo's B3 stock exchange rose to R177 billion (\$US45 billion), which was an increase of 40 per cent from R125 billion in 2017. If to this figure we add the profits of public-private state energy companies Petrobras and Electrobras, and Telecoms Oi, combined corporate profits reached R241 billion in 2018, a 100 per cent rise on the previous year. Excited by the outlook of a further rightward turn, foreign direct investment in Brazil between February 2018 and February 2019 hit $\$$ US89.5 billion, a significant increase on the $\$$ US6 7 billion flowing inwards the previous year. ${ }^{176}$

It was hoped and expected that Bolsonaro would take a knife to what capital continued to see as Brazil's bloated state - privatising highways, ports, and airports, resanctifying the independence of the central bank, unrolling a series of fiscal reforms, and, above all, gutting the pension system. ${ }^{177}$ The envisioned pension surgery would involve a radical reduction in public payments by R1 trillion, providing a sense of why 'domestic and international companies have latched on to the passage of the bill as a test case of whether the new adminis-

\footnotetext{
170 Fernandes 2019.

171 Roberts 2019.

172 Harris and Unzelte 2019.

173 Folha de São Paulo 2o19d.

174 The Economist 2018; Pearson and Magalhaes 2018.

175 Evans 2018.

176 Harris and Unzelte 2019.

177 Schipani and Leahy 2018; P. Anderson 2019.
} 
tration will be able to pass its broader reform agenda, including privatizations and deregulation.'178

Because it will necessitate a change to the social clauses of the 1988 Brazilian constitution, the pension reform requires three-fifths backing in the lower house of Congress - 308 of 513 members - and an equal proportion of the Senate, which has 81 seats. ${ }^{179}$ Turmoil within the ruling coalition, however, has dampened capital's expectations of the bill passing, and thus its confidence in Bolsonaro's rule more generally. ${ }^{180}$ In one signal of this shift in sentiment, the benchmark Bovespa stock-market index had already begun to fall in late March 2019, along with the Real currency, as it seemed increasingly probable that the pension-reform efforts would be delayed, at least to the second half of the year, and diluted in content. ${ }^{181}$

The idea of pension reform is unpopular, with over half of the population expressly hostile, and Bolsonaro is keen to avoid the unfavourable political fallout it would bring in its wake. ${ }^{182}$ Setting aside the intellectual dishonesty underpinning the claim that Brazil will collapse if it does not carry out pension restructuring, the genuine purpose of the changes is to undo once and for all the limited social compromise crystallised in the 1988 constitution. An enormous potential windfall to financial capital is being sold to the population as if it were in the nation's interest as a whole. ${ }^{183}$ Should a version of this bill pass eventually, it will precipitate new forms of social exclusion and inequality on top of already crippling disparities, with women and black workers hit hardest. ${ }^{184}$ At the same time, should it fail to pass in the relatively near feature, capital is likely to take flight and Bolsonaro's time in office could be short-lived.

Contradictions with specific sections of capital are also coming more strongly to the foreground. Agroindustry backed Bolsonaro decisively, but there are tensions between their interests and the early rhetorical moves of the government. For example, the anti-Chinese rhetoric of foreign-affairs minister Araujó is a problem for obvious reasons. The Chinese absorb 33\% of Brazil's agribusiness exports. China accounted for $76 \%$ of Brazil's soy exports and $20 \%$ of animal protein exports. In other less decisive sectors, China also plays an important role $-24 \%$ of Brazil's cotton exports, and $39 \%$ of cellulose. Similarly, agribusiness lobbying was important in determining that Bolsonaro did not

\footnotetext{
178 Harris and Unzelte 2019.

179 Wheatley 2019.

180 Harris and Schipani 2019a.

181 Harris and Schipani 2019a; Folha de São Paulo $2019 \mathrm{e}$.

182 Estela de Sousa Pinto 2019.

183 Fagnani 2019; Caccia Bava 2019.

184 Oliveira Teixeira 2019.
} 
follow through with his promise to move the Brazilian embassy in Israel from Tel Aviv to Jerusalem. The Arab Middle East spent \$US1.7 billion in Brazil's agribusiness sector between January and March 2019, accounting for $26 \%$ of Brazilian meat exports, $16 \%$ of cereals, and $15 \%$ of sugar. ${ }^{185}$

'The big problem that the United States has', Katz points out,

is that its natural allies in this would be the right-wing governments of Latin America; but they are governments whose dominant classes have very close relations with China, and the United States can offer them nothing in return. The dominant classes in Argentina and Brazil sell soy to China, and the United States is not going to buy that soy. The United States itself sells soy; in other words, it's a competitor. So what can agribusiness in Argentina and Brazil gain by entering into an agreement with its competitor, the United States, rather than its client, China?186

Bolsonaro's astonishing ascent to the highest seat of authority in Latin America's largest economy, in the fifth largest country in the world by area and population, was all the more discombobulating coming as it did in the wake of 13 years of rule by arguably the twenty-first century's most stable and institutionalised social-democratic party; yet another instance of the unravelling of the political centre in the rolling tsunami of global capitalist crisis, and still, so many particularities.

The policy paralysis in the opening act of this government cannot endure if it is to sustain the backing of capital. Itself an expression of the difficulty in appeasing a heterogeneous social base in a context of enduring world-market stagnation, the inertia of Bolsonaro's politics is transforming the Brazilian president from an unlikely asset into a liability in the eyes of capital. The question to which we cannot yet have an answer is whether the regime can continue to mobilise its hard nucleus of support through the libidinal bonds of the president's Twitter account, while stabilising a functioning coalition in Congress capable of rolling out pension reform, as well as the attendant packages of privatisation and deregulation. The unity across the cultural authoritarians, militarists and neoliberal technocrats that such a practical coalition would require was struck a blow in June 2019 with The Intercept's confirmation of long-held

185 Zafalon 2019.

186 Personal Interview, Claudio Katz, Buenos Aires, 5 May 2019. 
suspicions regarding Sérgio Moro's secret dealings with state prosecutors until then, Moro had been one of the likely candidates to bridge the regime's internal divides, and shore up its anti-politics war on corruption. Still, Paulo Guedes is grinding away at discussions with key congressional actors, outside the limelight, and a pension reform of some kind is likely to pass eventually. How diluted it becomes in the process will be closely watched by international financial markets. Meanwhile, there are few visible signs that Mourão is pining for any immediate or direct usurpation of power. A great little man, Bolsonaro has cohered, for a time at least, the necessary ideological 'pastiche of motifs' to fill the vacuum blown open by the PT's implosion.

And just how far has the PT degeneration progressed? It is an ailing hegemon of the country's left, but still the only operation of any size or weight, the institutional apparatus of which is likely to dominate all the more so a few years from now, as street mobilisations and strikes cede ground to the temporal pressures of approaching elections. The call to free Lula is a righteous one, and Moro's crimes in all likelihood altered the results of the 2018 electoral contest, with nefarious consequences. Justice should be sought on all accounts.

And yet there is clearly a danger of nostalgia and personalism in the singularity of the campaign to free Lula. An aged man who reigned over the rightward drift of Brazilian social democracy should be a less than beguiling figure for the Brazilian left, and his revival would be no answer to the historical fact that the PT's centrism played a critical role in ripening the conditions for the rise of a new far-right. Promise mainly lies elsewhere, even if establishing any left-party or movement independent of the petismo/anti-petismo binary would be a heroic task in the short and medium terms.

The labour movement was bureaucratised under PT rule, and is suffering under the structural informalisation of the world of work and deindustrialisation, as well as the legislative assaults on union rights begun under Temer and accelerated under Bolsonaro. But defensive strikes have been impressive in number, and the general strike of June 2019 is a basis from which to rebuild the rank-and-file. The promise of leftist social-movement rebellion in June 2013 was eclipsed for a number of years, as the sociological make-up and ideological leadership of street protests changed in 2015, 2016, and 2017. Yet \#EleNão, the women's mobilisations of March 8, 2019, the movements for justice for Marielle Franco, the movements against racism and for black and Indigenous liberation, and the emerging struggles around education are potential grounds for rearticulation.

The necessary work of winning back the informal layers of the working class who have been realigned with evangelism and Bolsonarismo will not be easily 
accomplished in the immediate future, but is best seen as a medium-term project, involving the slow, deliberate work of working-class recomposition.

\section{References}

Anderson, Jon Lee 2019, 'Jair Bolsonaro's Southern Strategy', The New Yorker, 25 March, available at: <https://www.newyorker.com/magazine/2019/o4/o1/jair -bolsonaros-southern-strategy $>$.

Anderson, Perry 2016, 'Crisis in Brazil', London Review of Books, 21 April: 15-22.

Anderson, Perry 2019, 'Bolsonaro's Brazil', London Review of Books, 7 February: 11-22.

Antunes, Ricardo 2015, 'Brasil: El Colapso del Gobierno Dilma y el PT', Herramienta, available at: $<$ http://ssl.herramienta.com.ar/articulo.php?id=2469 $>$, accessed 8 March 2018.

Banaji, Jairus 2017, 'The Political Culture of Fascism', Historical Materialism, 19 February, available at: $<$ http://www.historicalmaterialism.org/blog/political-culturefascism>, accessed 16 May 2019 .

BBC News 2019, 'Brazil Leader Criticised over Obscene Video', 6 March, available at: <https://www.bbc.com/news/world-latin-america-47473582>.

Boito Jr., Armando 2018, Reforma e crise polícia no Brasil: Os conflitos de classe nos governos do PT, Campinas: Editora da Unicamp.

Braga, Ruy 2012, A política do precariado: Do populismo à hegemonia lulista, São Paulo: Boitempo.

Braga, Ruy 2017, A rebeldia do precariado: Trabalho e neoliberalismo no Sul global, São Paulo: Boitempo.

Braga, Ruy 2019, 'From the Union Hall to the Church', Jacobin, 7 April, available at: <https://www.jacobinmag.com/2019/o4/bolsonaro-election-unions-labor -evangelical-churches $>$, accessed 15 May 2019.

Braga, Ruy and Sean Purdy 2019, 'A Precarious Hegemony: Neo-Liberalism, Social Struggles, and the End of Lulismo in Brazil', Globalizations, 16, 2: 201-15, <https://doi .org/10.1080/14747731.2018.1479013>.

Caccia Bava, Silvio 2019, 'Adeus ao desenvolvimento', Le Monde Diplomatique Brasil, April.

CEPAL 2019, Balance preliminar de las economías de América Latina y el Caribe, Santiago: CEPAL.

Della Coletta, Ricardo 2019, 'Araújo chega aos 100 dias de governo questionado por diplomatas e militares', Folha de São Paulo, 10 April.

Dias, Marina and Patrícia Campos Mello 2019, 'Falo o que Bolsonaro não fala, afirma Mourão', Folha de São Paulo, 10 April. 
Dieguez, Consuelo 2019, 'O chanceler do regresso: Os planos de Ernesto Araújo para salvar o Brasil e o Occidente', piauí, 151.

Escobar, Herton 2019, 'In Brazil, “Useful Idiots” Protest Cuts to Research and Education', Science, 17 May, available at: <https://www.sciencemag.org/news/2019/o5/brazil -useful-idiots-protest-cuts-research-and-education $>$, accessed 30 May 2019.

Esquerda Diário 2019, 'Governo Bolsonaro promove ataques ao IBGE', 7 June, available at: <http://www.esquerdadiario.com.br/Governo-Bolsonaro-promove-ataques -ao-IBGE $>$, accessed 20 June 2019.

Estela de Sousa Pinto, Ana 2019, '51\% são contra e 41\% apoiam reforma de Previdência', Folha de São Paulo, 10 April.

Evans, Peter 2018, 'Brazil: An Unfolding Tragedy', The Berkeley Review of Latin American Studies, Fall, available at: <https://clas.berkeley.edu/research/brazil-unfolding -tragedy $>$, accessed 30 May 2019.

Fagnani, Eduardo 2019, 'O propósito velado da "reforma” da Previdência', Le Monde Diplomatique Brasil, April.

Fernandes, Anaïs 2019, 'FMI reduz projeção para crescimento global em 2019', Folha de São Paulo, 10 April.

Fishman, Andrew, Rafael Moro Martins, Leandro Demori, Alexandre de Santi and Glenn Greenwald 2019, 'Breach of Ethics. Exclusive: Leaked Chats between Brazilian Judge and Prosecutor who Imprisoned Lula Reveal Prohibited Collaboration and Doubts over Evidence', The Intercept, 9 June, available at: <https://theintercept .com/2019/o6/og/brazil-lula-operation-car-wash-sergio-moro/>.

Fogel, Benjamin 2018, 'Brazil's Never-ending Crisis', Catalyst, 2, 2, available at: <https:// catalyst-journal.com/vol2/no2/brazils-never-ending-crisis>, accessed 30 May 2019.

Fogel, Benjamin 2019a, 'Bolsonaro's Three-month Rule a Disaster', The Mail and Guardian, 12 April, available at: <https://mg.co.za/article/2019-04-12-oo-bolsonaros -three-month-rule-a-disaster/>, accessed 31 May 2019.

Fogel, Benjamin 2019b, 'Brazil: Corruption as a Mode of Rule', NACLA Report on the Americas, 51, 2: 153-8, <https://doi.org/10.108o/10714839.2019.1617476>.

Folha de São Paulo 2019a, "Não vou perder tempo para comentar pesquisa do Datafolha", diz Bolsonaro', 8 April, available at: <https:/www1.folha.uol.com.br/ poder/2019/o4/nao-vou-perder-tempo-para-comentar-pesquisa-do-datafolha-diz -bolsonaro.shtml>.

Folha de São Paulo 2019b, 'Maioria aprova a participação de militares no governo, diz Datafolha', 8 April.

Folha de São Paulo 2019c, 'Moro é aprovado por 59\%, e ministro do Turismo, pivô dos laranjas, tem 11\%', 8 April.

Folha de São Paulo 2019d, 'Otimismo com economia cai depois de Bolsonaro assumir a Presidência', 8 April. 
Folha de São Paulo 2019e, 'Reforma de Bolsonaro não é "de coração", diz Guedes em Washington', 12 April.

Folha de São Paulo 2019f, 'Por reforma, governadores vão a Brasília e devem assinar manifesto conjunto', 6 June, available at: <https://www1.folha.uol.com.br/mercado /2019/o6/por-reforma-governadores-vao-a-brasilia-e-devem-assinar-manifesto -conjunto.shtml>, accessed 6 June 2019.

Freixo, Marcelo 2019, 'O pacote de Moro nasce velho', Le Monde Diplomatique Brasil, March.

Fuccille, Alexandre 2019, 'Notas para entender os militares brasileiros na atualidade', Le Monde Diplomatique Brasil, March.

Garcia, Ana 2019, 'Brazil Under Bolsonaro: Social Base, Agenda, and Perspectives', The Bullet, 15 April, available at: <https://socialistproject.ca/2019/o4/brazil-under -bolsonaro-social-base-agenda-and-perspectives/>.

Gill, Lesley 2016, A Century of Violence in a Red City: Popular Struggle, Counterinsurgency, and Human Rights in Colombia, Durham, NC: Duke University Press.

Greenwald, Glenn, Leandro Demori and Betsy Reed 2019, 'How and Why The Intercept Is Reporting on a Vast Trove of Materials about Brazil's Operation Car Wash and Justice Minister Sergio Moro', The Intercept, 9 June, available at: <https://theinter cept.com/2019/o6/og/brazil-archive-operation-car-wash/>.

Greenwald, Glenn and Victor Pougy 2019, 'Hidden Plot. Exclusive: Brazil's Top Prosecutors who Indicted Lula Schemed in Secret Messages to Prevent his Party from Winning 2018 Election', The Intercept, 9 June, available at: <https://theinter cept.com/2019/o6/og/brazil-car-wash-prosecutors-workers-party-lula/>.

Grigera, Juan, Jeffery R. Webber, Ludmila Abilio, Ricardo Antunes, Marcelo Badaró Mattos, Sabrina Fernandes, Rodrigo Nunes, Leda Paulani and Sean Purdy 2019, 'The Long Brazilian Crisis: A Forum', Historical Materialism, available at: <http:// www.historicalmaterialism.org/articles/long-brazilian-crisis-forum $>$, accessed 1 June 2019.

Harris, Bryan and Andres Schipani 2019a, 'Jair Bolsonaro's Twitter Habit Endangers Brazil's Reform Plans', Financial Times, 29 March.

Harris, Bryan and Andres Schipani 2019b, 'Brazil Minister's Dismissal Raises Doubts over Bolsonaro', Financial Times, 8 April.

Harris, Bryan and Andres Schipani 2019c, 'Brazil's Bolsonaro Keeps it in the Family', Financial Times, 6 May, available at: <https://www.ft.com/content/2fad23d2-6cdf -11e9-8oc7-6oee53e6681d $>$, accessed 3 June 2019.

Harris, Bryan and Andres Schipani 2019d, 'Brazil's Shrinking GDP Fuels Recession Fears', Financial Times, 3 o May, available at: <https://www.ft.com/content/oac1376e -8221-11eg-b592-5fe435b57a3b >, accessed 31 May 2019. 
Harris, Bryan and Carolina Unzelte 2019, 'Brazil's Business Optimism Bounces back under Bolsonaro', Financial Times, 1 April.

Jornal do Brasil 2019, 'Cidades pelo Brasil registram greve geral e protestos', 14 June, available at: <http://www.jb.com.br/pais/2019/o6/1004874-cidades-pelo-brasil-regis tram-greve-geral-e-protestos.html $>$, accessed 19 June 2019.

Leahy, Joe and Andres Schipani 2018, 'Brazil's Gun-loving Bolsonaro Clan Seeks to Build Political Dynasty', Financial Times, 12 October.

Levenson, Deborah T. 2013, Adiós Niño: The Gangs of Guatemala City and the Politics of Death, Durham, NC: Duke University Press.

Levinas, Lena 2019, 'A ampliação de benefício é mais uma cortina de fumaça?', Folha de São Paulo, 12 April.

Londoño, Ernesto and Letícia Casado 2019, 'Bolsonaro's Popularity Sinks after a Rocky 100 Days in Brazil', New York Times, 14 April.

Marques, José 2019, 'Para maioria da população, golpe de 1964 deveria ser desprezado, diz Datafolha', Folha de São Paulo, 6 April.

Mena, Fernanda 2019, 'Maioria é contra pontos-clave de pacote anticrime de Moro', Folha de São Paulo, 11 April.

Mussi, Daniela and Alvaro Bianchi 2018, 'Rise of the Radical Right', NACLA Report on the Americas, 50, 4: 351-5.

Nobre, Marcos 2019, 'O caos como método: Manter o colapso institucional é o modo de Bolsonaro garantir a fidelidade de seus eleitores', piauí, 151, available at: <https:// piaui.folha.uol.com.br/materia/o-caos-como-metodo/>.

Nunes, Rodrigo 2019, 'Jair Bolsonaro Is Weaker than He Looks', Jacobin, 10 June, available at: <https://jacobinmag.com/2019/o6/bolsonaro-war-on-reality-education -protests $>$, accessed 16 June 2019.

O Globo 2019, 'Saiba quem é Gustavo Montezano, novo presidente do BNDES', 17 June, available at: <https://oglobo.globo.com/economia/saiba-quem-gustavo -montezano-novo-presidente-do-bndes-23746941>, accessed 20 June 2019.

Oliveira Teixeira, Marilane 2019, 'A desestruturação do mercado de trabalho', Le Monde Diplomatique Brasil, April.

Oro, Arí Pedro and Marcelo Tadvald 2019, 'Consideraciones sobre el campo evangélico brasileño', Nueva Sociedad, 280: 55-67.

Oualalou, Lamia 2019, 'Los evangélicos y el hermano Bolsonaro', Nueva Sociedad, 280: 68-77.

Pearson, Samantha and Luciana Magalhaes 2018, 'Conservative's Win Signals Sharp Rightward Turn in Brazil', Wall Street Journal, 29 October, available at: <https://www.wsj.com/articles/brazilians-head-to-polls-in-divisive-presidential -election-1540724400>, accessed 31 May 2019.

Penido, Ana 2019, 'A educação nas Forças Armadas', Le Monde Diplomatique Brasil, March. 
Phillips, Dom 2018a, 'Jair Bolsonaro: Brazil Presidential Frontrunner Stabbed at Campaign Rally', The Guardian, 7 September, available at: <https://www.theguard ian.com/world/2018/sep/o6/brazil-jair-bolsonaro-far-right-presidential-candidate -stabbed $>$, accessed 1 June 2019.

Phillips, Dom 2018b, 'Bolsonaro to Abolish Human Rights Ministry in Favour of Family Values', The Guardian, 10 December, available at: <https://www.theguardian.com/ world/2018/dec/o6/outcry-over-bolsonaros-plan-to-put-conservative-in-charge-of -new-family-and-women-ministry>, accessed 5 June 2019.

Phillips, Tom 2019, 'Students Protest across Brazil over Jair Bolsonaro's Sweeping Cuts to Education', The Guardian, 3o May, available at: <https://www.theguardian.com/ world $/ 2019 / \mathrm{may} / 31 /$ students-protest-across-brazil-over-jair-bolsonaros-sweeping -cuts-to-education>, accessed 31 May 2019.

Pinheiro da Fonseca, Joel 2019, 'A farsa e a tragédia da educação', Folha de São Paulo, 9 April, available at: <https://www1.folha.uol.com.br/colunas/joel-pinheiro-da -fonseca/2019/o4/a-farsa-e-a-tragedia-da-educacao.shtml >.

Political Economy Research Centre (PERC) 2019, Brazil under Bolsonaro: Alfredo Saad-Filho in Conversation with Jeffery R. Webber, 14 March, Goldsmiths, University of London, available at: <https://soundcloud.com/goldsmithsuol/brazil-under -bolsonaro>, accessed 27 April 2019.

Poulantzas, Nicos 1978, State, Power, Socialism, London: Verso.

Rathbone, John Paul 2019, 'The Mask of Bolsonaro's Guru, Olavo de Carvalho, Slips', Financial Times, 22 March.

Redden, Elizabeth 2019, 'Brazil's Bolsonaro Takes on Philosophy, Sociology', Inside Higher Ed, 29 April, available at: <https://www.insidehighered.com/quicktakes/ 2019/04/29/brazils-bolsonaro-takes-philosophy-sociology>, accessed 3o May 2019.

Roberts, Michael 2019, 'Global Slump: The Trade and Technology Trigger', Michael Roberts Blog, 26 May, available at: <https://thenextrecession.wordpress.com/ 2019/o5/26/global-slump-the-trade-and-technology-trigger/>, accessed 31 May 2019. Rocha de Barros, Celso 2019, 'A queda: Hipóteses sobre o governo Bolsonaro', piauí, 15 o. Saad-Filho, Alfredo 2016, 'A Coup in Brazil?', Jacobin, 23 March, available at: <http:// jacobinmag.com/2016/o3/dilma-rousseff-pt-coup-golpe-petrobras-lavajato/>, accessed 8 March 2018.

Saad-Filho, Alfredo and Armando Boito 2015, 'Brazil: The Failure of the PT and the Rise of the "New Right", in Socialist Register 2016: The Politics of the Right, edited by Leo Panitch and Greg Albo, pp. 213-30, New York: Monthly Review Press.

Saad-Filho, Alfredo and Lecio Morais 2018, Brazil: Neoliberalism versus Democracy, London: Pluto Press.

Saldaña, Paulo, Talita Fernandes and Gustavo Uribe 2019, 'Missão é acalmar os ânimos no MEC, afirma Weintraub', Folha de São Paulo, 10 April. 
Saldaña, Paulo and Gustavo Uribe 2019, 'Bolsonaro troca Vélez por economista inexperiente em educação no MEC', Folha de São Paulo, 9 April.

Schipani, Andres 2018, 'Jair Bolsonaro's Inner Circle: Who's Who', Financial Times, 22 November, available at: <https://www.ft.com/content/cc6331fc-ecde-11e8-8180 -9cf212677a57>, accessed 6 June 2019.

Schipani, Andres 2019, 'Will Jair Bolsonaro Be a Brazilian King Lear?', Financial Times, 25 January.

Schipani, Andres and Bryan Harris 2019, 'Brazil's Generals Viewed as Voice of Moderation in Populist Government', Financial Times, 31 March.

Schipani, Andres and Joe Leahy 2018, 'Brazil's Bolsonaro Aims to Rule with "Bull, Bullet, and Bible" Bloc', Financial Times, 9 October.

Schipani, Andres and John Paul Rathbone 2019, 'Brazil Economy Minister Vows Return of "Order" in Sweeping Reforms', Financial Times, 11 February, available at: <https:// www.ft.com/content/c8925b18-2b25-11e9-a5ab-ff8ef2b976c7>, accessed 6 June 2019.

Sears, Alan 2014, The Next New Left: A History of the Future, Halifax, NS: Fernwood Publishing Co. Ltd.

Singer, André 2018, O lulismo em crise: Um quebra-cabeça do período Dilma (2011-2016), São Paulo: Companhia das Letras.

Singer, André and Gustavo Venturi 2019, 'Sismografia de um terremoto eleitoral', in Democracia em risco? 22 ensaios sobre o Brasil Hoje, São Paulo: Companhia das Letras.

The Economist 2018, 'Jair Bolsonaro Will Be Brazil's next President', 29 October, available at: <https://www.economist.com/the-americas/2018/10/29/jair-bolsonaro-will -be-brazils-next-president $>$, accessed 31 May 2019.

Toscano, Alberto 2017, 'Notes on Late Fascism', Historical Materialism, 2 April, available at: <http://www.historicalmaterialism.org/blog/notes-late-fascism>, accessed 16 May 2019.

Toscano, Alberto 2019, 'Observations on Capitalist Folklore', Viewpoint Magazine, 24 April, available at: <https://www.viewpointmag.com/2019/o4/24/observations -on-capitalist-folklore/>, accessed 17 May 2019.

Traverso, Enzo 2019, 'Interpretar la era de la violencia global', Nueva Sociedad, 280: 163-79.

Uribe, Gustavo and Talita Fernandes 2019, 'Após início com desgastes e isolamento, Bolsonaro revê estrutura de governo', Folha de São Paulo, 10 April.

Vianna, Adriana 2019, 'Políticas da morte e seus fantasmas', Le Monde Diplomatique Brasil, March.

Victor, Fabio 2019, 'História, volver', piauí, 150.

Webber, Jeffery R. 2017, The Last Day of Oppression, and the First Day of the Same: The Politics and Economics of the New Latin American Left, Chicago: Haymarket Books. 
Wheatley, Jonathan 2019, 'Brazil Unveils Long-awaited Pensions Reform Proposal', Financial Times, 20 February.

Zafalon, Mauro 2019, 'Cem dias de Bolsonaro desafiam o agro a contornar vies ideológico', Folha de São Paulo, 9 April.

Zibechi, Raúl 2012, Brasil potencia: entre la integración regional y un nuevo imperialismo, Málaga: Zambra/Baladre. 